\title{
Experience Base for Radioactive Waste Thermal Processing Systems, a Preliminary Survey
}

\author{
John Mayberry ${ }^{a}$ \\ Ray Geimer ${ }^{a}$ \\ Robert Gillins ${ }^{a}$ \\ E. Malone Steverson ${ }^{a}$ \\ David Dalton ${ }^{\mathrm{a}}$ \\ Gary L. Anderson
}

Published April 1992

\section{Idaho National Engineering Laboratory \\ EG\&G Idaho, Inc. \\ Idaho Falls, Idaho 83415}

\author{
Prepared for the \\ U.S. Department of Energy \\ Office of Environmental Restoration and Waste Management \\ Under DOE Idaho Field Office \\ Contract DE-ACO7-76ID01570
}


Experience Base for Radioactive Waste Thermal Processing Systems, a Preliminary Survey

Prepared by:
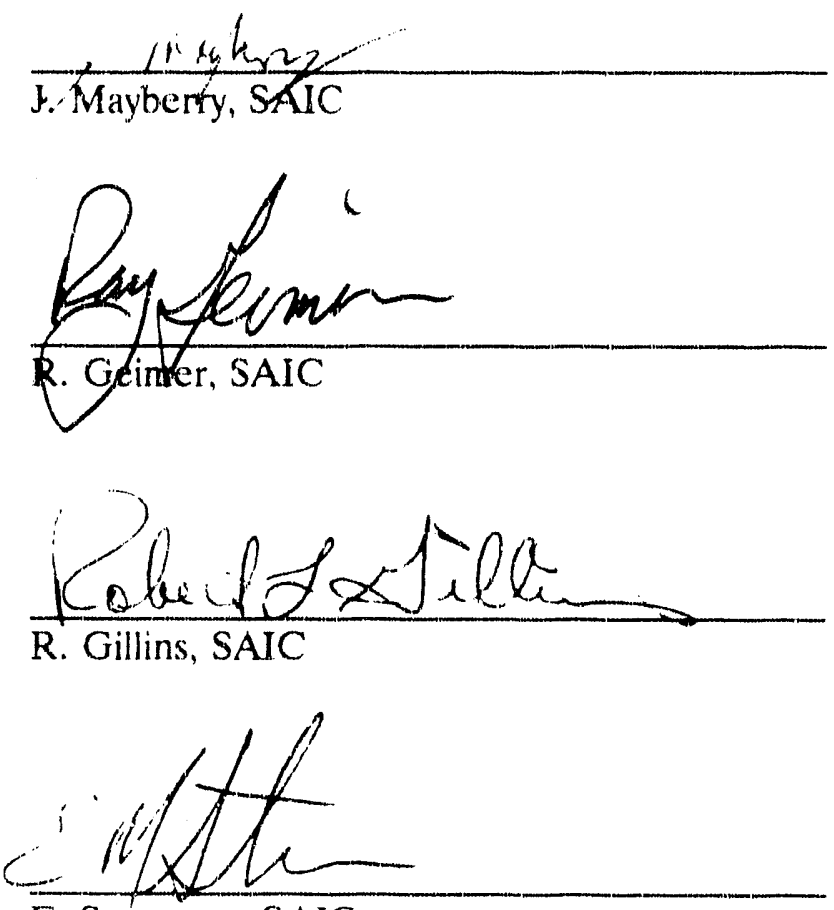

E. Steverson, SAIC

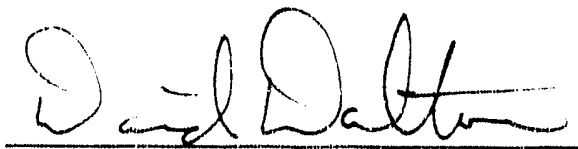

D. Dalton, SAIC
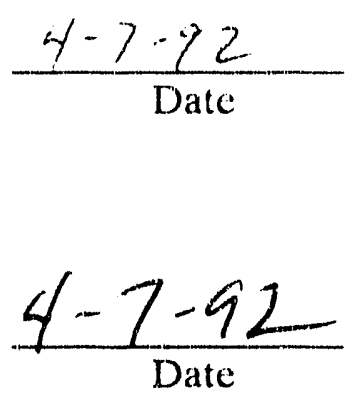

$4-7-92$

Date
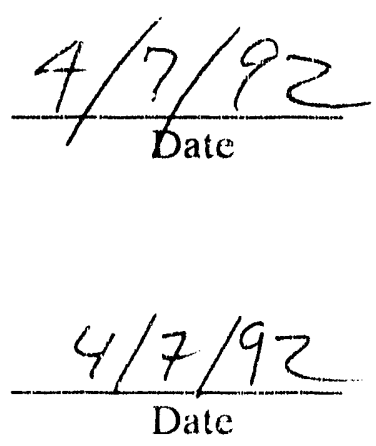

G. L. Anderson

Reviewed and Approved by:
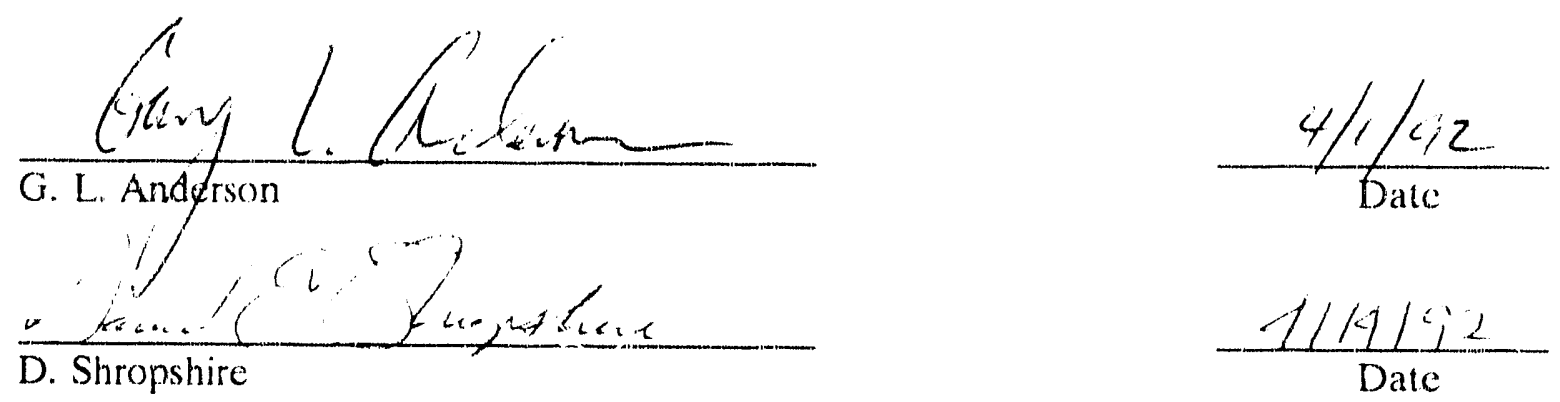


\begin{abstract}
In the process of considering thermal technologies for potential treatment of the Idaho National Engineering Laboratory mixed transuranic contaminated wastes, a preliminary survey of the experience base available from Radioactive Waste Thermal Processing Systems is reported.

A list of known commercial radioactive: waste facilities in the United States and some international thermal treatment facilities are provided. Survey focus is upon the U.S. Department of Energy thermal treatment facilities. A brief facility description and a preliminary summary of facility status, and problems experienced is provided for a selected subset of the DOE facilities.
\end{abstract}




\section{ACKNOWLEDGEMENTS}

This report was prepared for the Waste Technology Department of EG\&G Idaho, Inc., under contract to the U.S. Department of Energy Office of Technology Development Idaho Field Office. Funding was provided under FY-91 Thermal Processing Technologies Technical Task Plan ID-0502-DT, 1991, and ID-040E-2D, 1992. 


\section{CONTENTS}

ABSTRACT $\ldots \ldots \ldots \ldots \ldots \ldots \ldots \ldots \ldots \ldots \ldots \ldots \ldots \ldots \ldots \ldots \ldots \ldots \ldots \ldots \ldots$

ACKNOWLEDGEMENTS $\ldots \ldots \ldots \ldots \ldots \ldots \ldots \ldots \ldots \ldots \ldots \ldots \ldots \ldots$

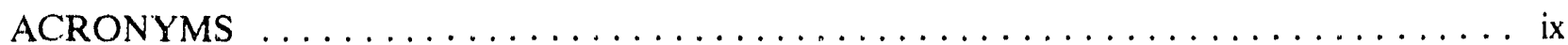

1. INTRODUCTION $\ldots \ldots \ldots \ldots \ldots \ldots \ldots \ldots \ldots \ldots \ldots \ldots \ldots \ldots \ldots \ldots$

2. IDENTIFICATION OF RADIOACTIVE WASTE THERMAL PROCESSING

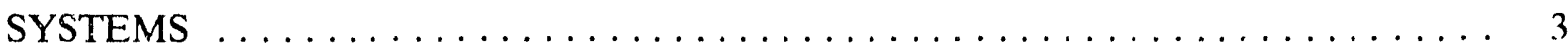

3. EXPERIENCE FROM SELECTED THERMAL PROCESSING FACILITIES . . . . . 14

3.1 Summary of Facility Problem Areas $\ldots \ldots \ldots \ldots \ldots \ldots \ldots \ldots \ldots \ldots$

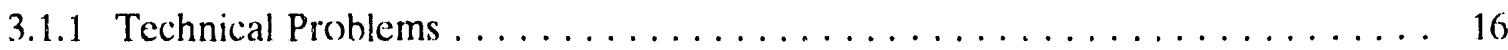

3.1 .2 Regulatory/Public Problems ....................... 19

3.1 .3 Institutional Problems . . . . . . . . . . . . . . . . . . . . . . . . . . 19

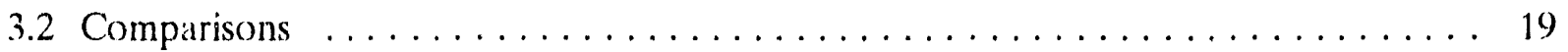

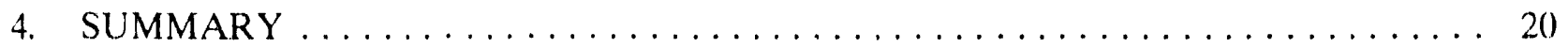

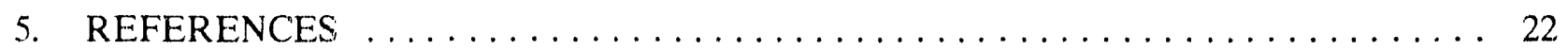

Appendix A-Idaho National Engineering Laboratory (INEL) $\ldots \ldots \ldots \ldots \ldots \ldots \ldots$

Appendix B-Waste Experimental Reduction Facility (WERF) $\ldots \ldots \ldots \ldots \ldots \ldots$. $\ldots \ldots$

Appendix C-Los Alamos National Laboratory (LANL)-Controlled Air Incincrator (CAI) . . C-1 Appendix D--Mound Laboratory-Joule-Heated Glass Melter $\ldots \ldots \ldots \ldots \ldots \ldots \ldots \ldots$ D.1

Appendix E-K-25--Toxic Substances Control Act (TSCA) Incinerator $\ldots \ldots \ldots \ldots \ldots \ldots$ E-1

Appendix F-Rocky Flats Plant (RFP)-Fluidized Bed Incinerator (FBI) Demonstration ... . F-1 Appendix G-Savannah River Site (SRS)-Beta-Gamma Incinerator (BGI) . . . . . . . G-1 Appendix H-Savannah River Site (SRS)-Consolidated Incineration Facility (CIF) . . . . . H-1 Appendix I-Savannah River Site (SRS)-Defense Wastes Processing Facility (DWPF) . . . . I-1 Appendix J.-Scientific Ecology Group (SEG) Incinerator $\ldots \ldots \ldots \ldots \ldots \ldots \ldots \ldots \ldots$ 


\section{TABLES}

1. Radioactive thermal processing facilities $\ldots \ldots \ldots \ldots \ldots \ldots \ldots \ldots \ldots \ldots$

2. Commercial radioactive waste thermal treatment facilities $\ldots \ldots \ldots \ldots \ldots \ldots \ldots$

3. International radioactive waste thermal treatment facilities $\ldots \ldots \ldots \ldots \ldots \ldots \ldots$

4. Summary of planned DOE thermal treatment projects. $\ldots \ldots \ldots \ldots \ldots \ldots \ldots \ldots$

5. Summary of constructed DOE thermal facilities. $\ldots \ldots \ldots \ldots \ldots \ldots \ldots \ldots \ldots \ldots$

6. Reasons for shut down or standby of constructed facilitics. $\ldots \ldots \ldots \ldots \ldots \ldots \ldots$

7. Selected thermal processing facilities. $\ldots \ldots \ldots \ldots \ldots \ldots \ldots \ldots \ldots \ldots \ldots \ldots$ 


\section{ACRONYMS}

BGI

CAI

CIF

DOE

DWPF

EPA

FBI

FRP

$\mathrm{HCl}$

HEPA

HFS

HLW

INEL

LANL

L.LNL

LLW

ML

MW

NEPA

NESHAP
Beta-Gamma Incinerator

Controlled Air Incinerator

Consolidated Incineration Facility

Department of Energy

Defense Waste Processing Facility

Environmental Protection Agency

fluidized bed incinerator

fiber reinforced plastic

hydrochloric acid

high-efficiency particulate air filters

Hanford Site

high-level waste

Idaho National Engineering Laboratory

Los Alamos National Laboratory

Lawrence Livermore National Laboratory

low-level waste

Mound Laboratory

mixed waste

National Environmental Policy Act of 1969

National Emission Standards for Hazardous Air Pollutants 
ORNL

Oak Ridge National Laboratory

PCB

polychlorinated biphenyl

PCC

primary combustion chamb/sr

PRA

probabilistic risk assessment

PREPP

Process Experimental Pilot Plant

RAM

reliability, availability, and maintainability

RCRA

Resource Conservation and Recovery Act

RFP

Rocky Flats Plant

RWMC

Radioactive Waste Management Complex

SCC

secondary combustion chamber

SEG

Scientilic Ecology Group

SRS

Savannah River Site

TRU

transuranic

TSCA

Toxic Waste Control Act

WERF

Waste Experimental Reduction Facility

WIPP

Waste Isoiation Pilot Plant 


\section{Experience Base for Radioactive Waste Thermal Processing Systems, a Preliminary Survey}

\section{INTRODUCTION}

Since the early 1950's, transuranic (TRU) contaminated waste has been buried and/or stored at the Idaho National Engineering Laboratory 's (INEL) Radioactive Waste Management Complex (RWMC). Most of the radioactive wastes also contain Resource Conservation and Recovery Act (RCRA) hazardous materials and are, therefore, designated as "mixed wastes."

Thermal processing technologies have been identified via preliminary systems design and technology screening studies ${ }^{1-3}$ as key elements in the preferred ex-situ treatment options for mixed TRU contaminated waste and soil at the INEL.

Thermal treatment technologies are generally defined as technologies that use heat energy to change the physical and chemical form of the material being processed to a more desirable form. Thermal treatment of the INEL waste could reduce the overall waste volume, destroy the hazardous organics and potentially stabilize the noncombustible hazardous and TRU elements in an essentially nonleachable glass/ceramic waste form for final disposal. Thermal devices encompass a range of technologies from standard incineration processes (c.g., rotary kiln incinerator) to melter based technologies (e.g., joule-heated melter).

Using thermally based technologies for waste treatment is not a new concept, but rather a well investigated and time-proven approach. Over 200 commercial incineration facilities have been constructed and operated for the treatment of strictly hazardous (nonradioaclive) waste. ${ }^{4}$ The United States Department of Energy (DOE) and international sectors have undertaken a considerable number of radioactive waste thermal treatment projects. These projects represent a potentially valuable source of experience relative to the selection, design, and implementation of potentia! mixed waste thermal treatment systems at the INEL.

The purpose of this study was to provide an initial identification, current status, and scoping of experience for thermal treatment projects involving radioactive wast i treatment within the DOE system. The projects identified include not only those that have been constructed and are being operated, but those recently shut down, still under construction, or planned. The identified planned facilities within the DOE system are not all inclusive as there are varying degrees of commitment to planned facilities. This area is constantly changing.

The identification of an experience base is important 10 provide opportunity for project planners and engineers to benefit from the experiences of past thermal treatment projects. 
A partial list of commercial and international facilities is included to provide perspective as to the extent of thermal technology based treatment systems being used on radioactive waste outside the DOE system. No attempt was made to provide an all inclusive list. 


\section{IDENTIFICATION OF RADIOACTIVE WASTE THERMAL PROCESSING SYSTEMS}

The first phase of this study inwolved the identification of thermal treatment systems in existence or planned followed by collection and compilation of experience data on a sected sample of the identified systems. The study focused on radioactive waste the: mal treatment projects within the DOE. Some effort was also spent in identifying projects that have been undertaken in the United States commercial and the internicional radioactive waste communities to provide some perspective on the state-of-radioactive waste treatment outside of the DOE. This allows some comparison between the status of DOE projects and other organizations performing similar efforts. The list of foreign and commercial projecis generated is not exhaustive. Future efforts recommended would collect and exnmine additicnal data in this area.

Existing reports were used to compile the initial data on present DOE thermal treatment facilities. ${ }^{5,6}$ In addition, personnel familiar with projects throughout the DOE were then consulted to ensure the assembly of a comprehensive list. For this study, only facilities built after 1970 were selected. It was judged unlikely that thermat systems built before 1970 would provide information pertinent to this study and locating personnel familiar with such fachities posed difficulties. Table 1 provides a detailed list of identified DOE thermal treatment projects, by site and includes information on the type of technology, current status (operating, startup, standby, etc.), lype of waste targeted, and point of contact for information on each facility.

Table 2 provides a partial list of the known commercial radioactive waste facilities in the U.S. and Table 3 contains a list of some international thermal treatment facilities. A comprehensive evaluation in these latter (wo areas was outside the scope of this study. Thes tables show that a significant amount of experience base information may be available from sources outside the DOE. The data suggest that many thermal treatment projects for radioactive waste have been constructed and that. particularly internationally, incineration of radioactive waste is an accepted and wellestablished treatment method. Japan has been particularly aggressive in the construction of thermal treatment facilities for radioactive wastes. It should be noted that the data included on international facilities is largley based on a 1983 report. Papers presented in the recent International Incineration Conference indicate the international community appears to be underaking a number of new projects.

Table 4 shows a summary of the planned DOE thermal facilities by technology type. As the table shows, there are seven DOE thermal lacilities planned, with the majority in the conceptual planning stage. Five of the seven facilities are being proposed to process mixed waste and are thus being driven by the mixed waste treatment needs of each particular site. The remaining two facilities would process high-level waste (HLW) into a glass waste form to allow for stable long-term storage. 


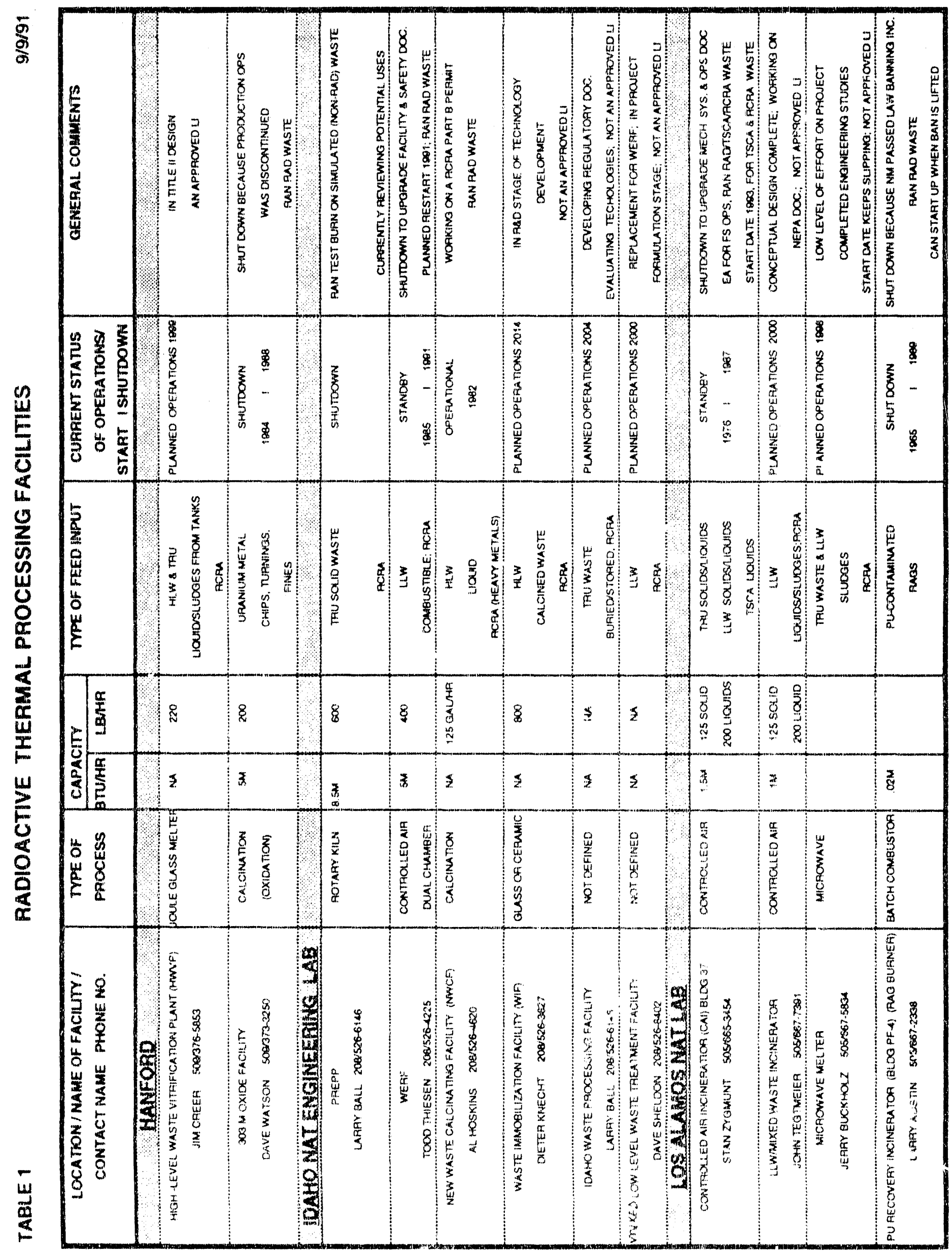




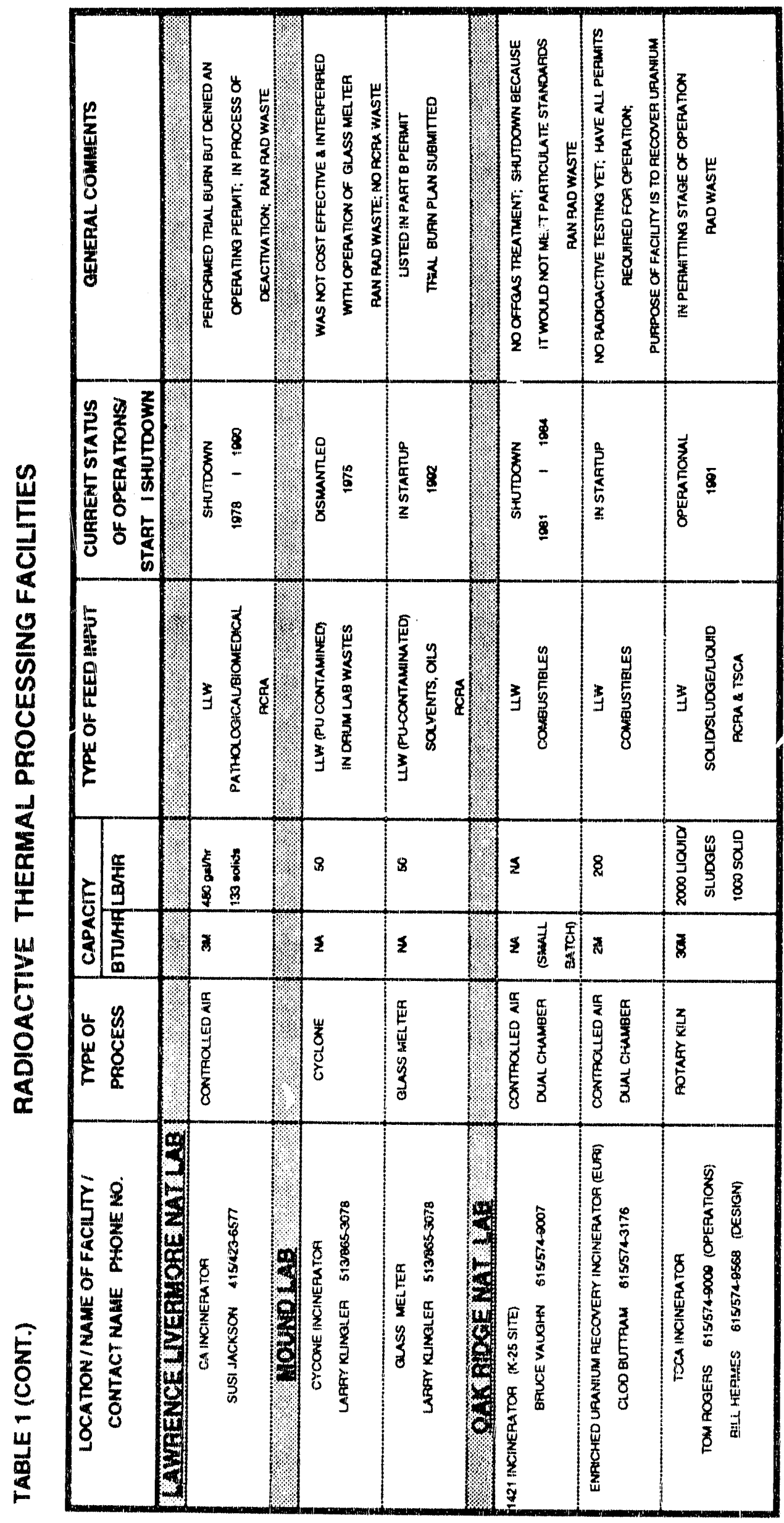




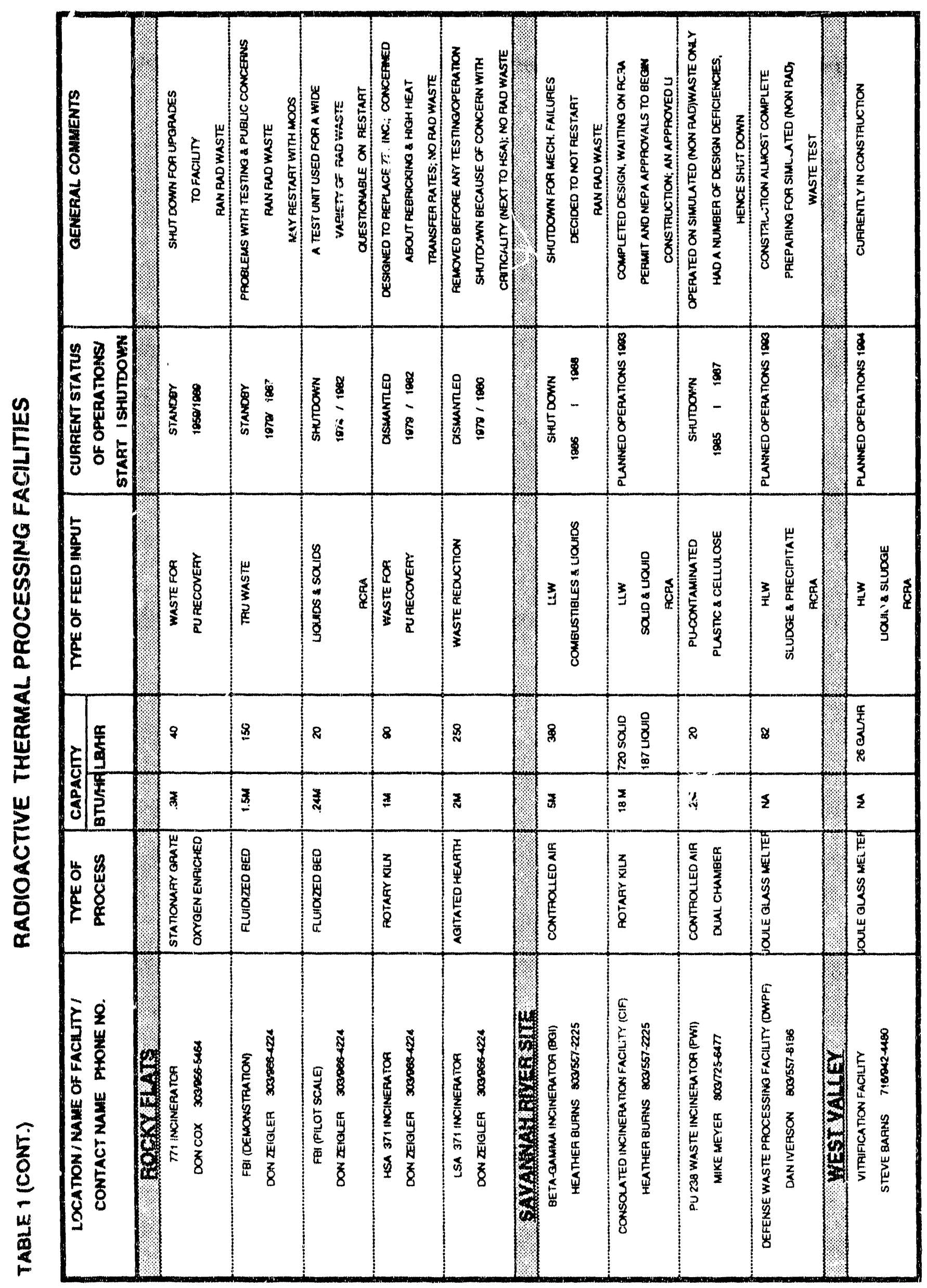




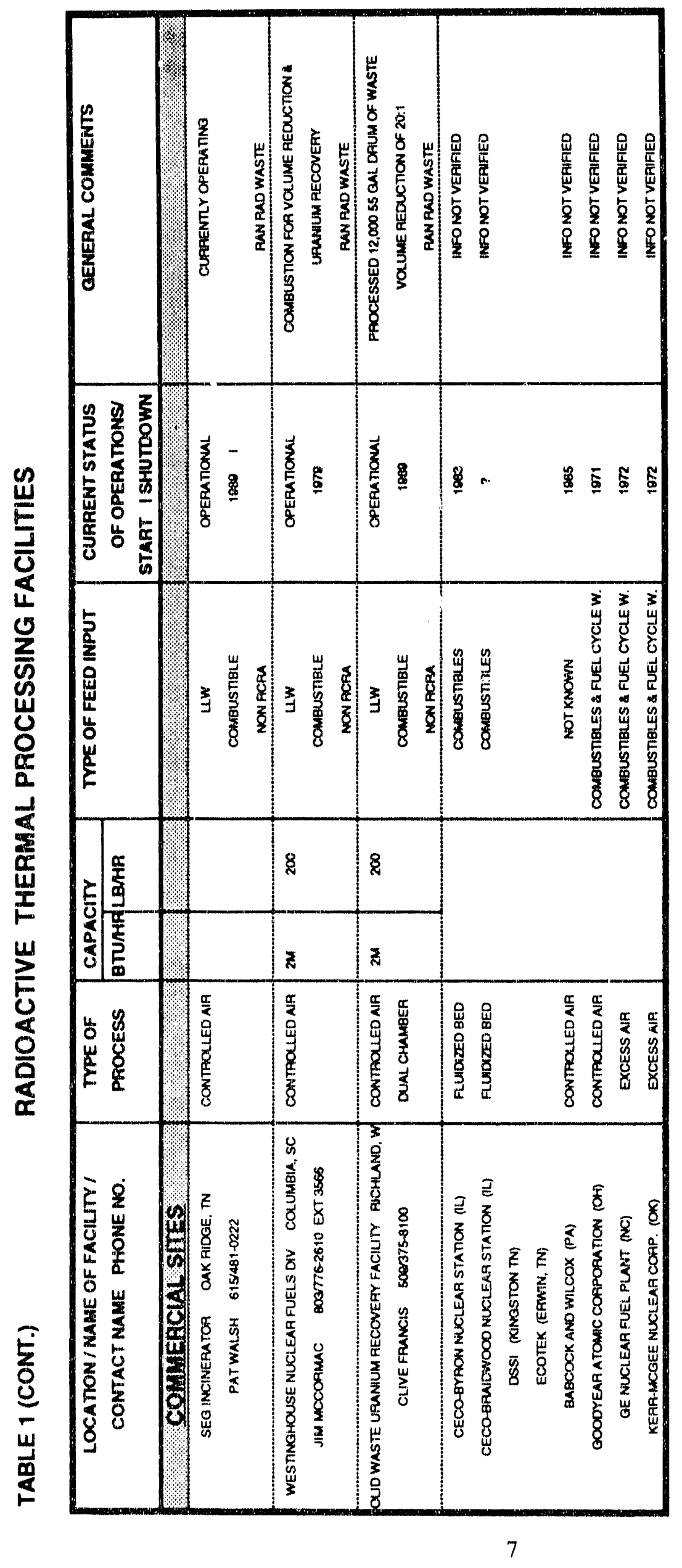




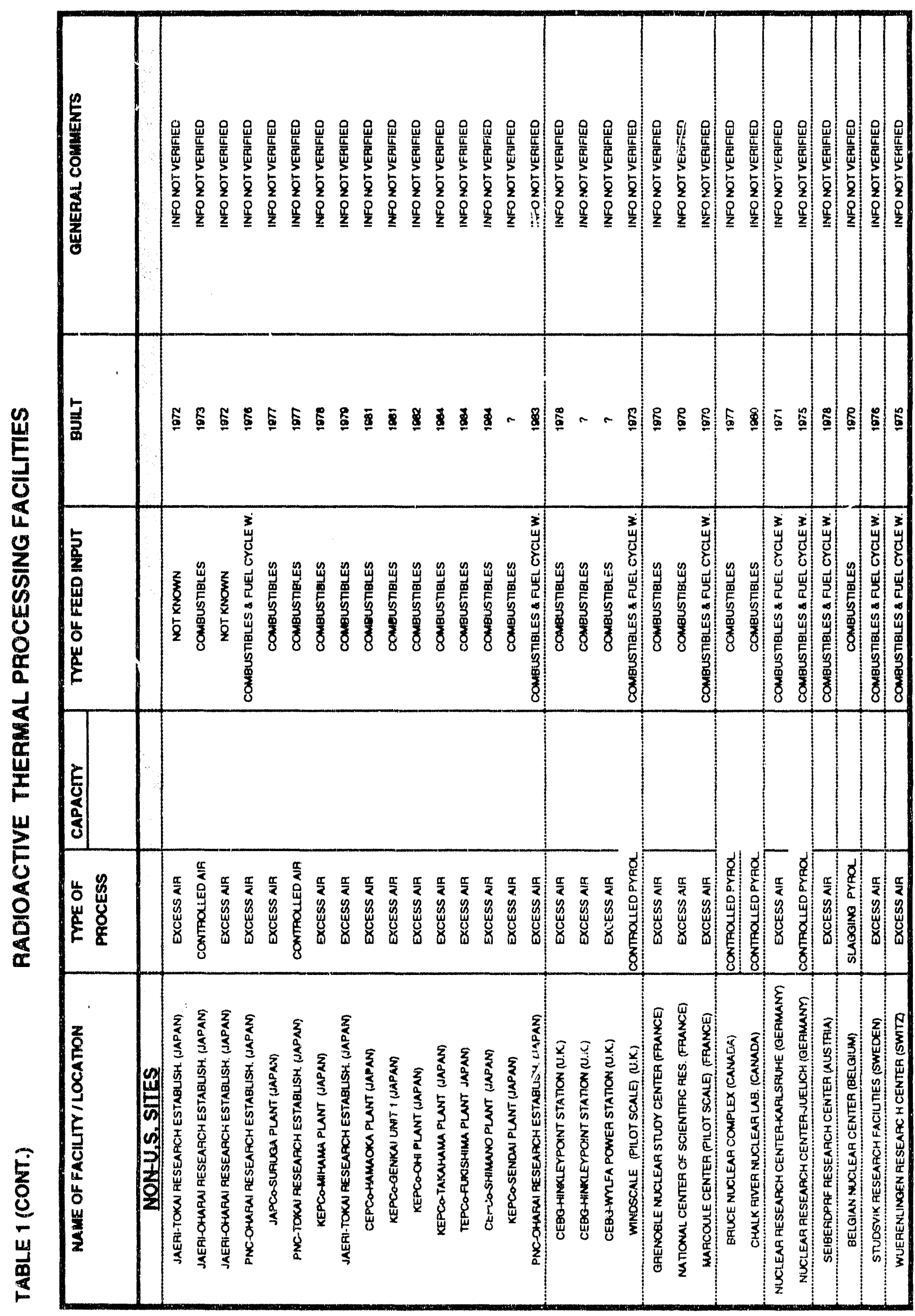




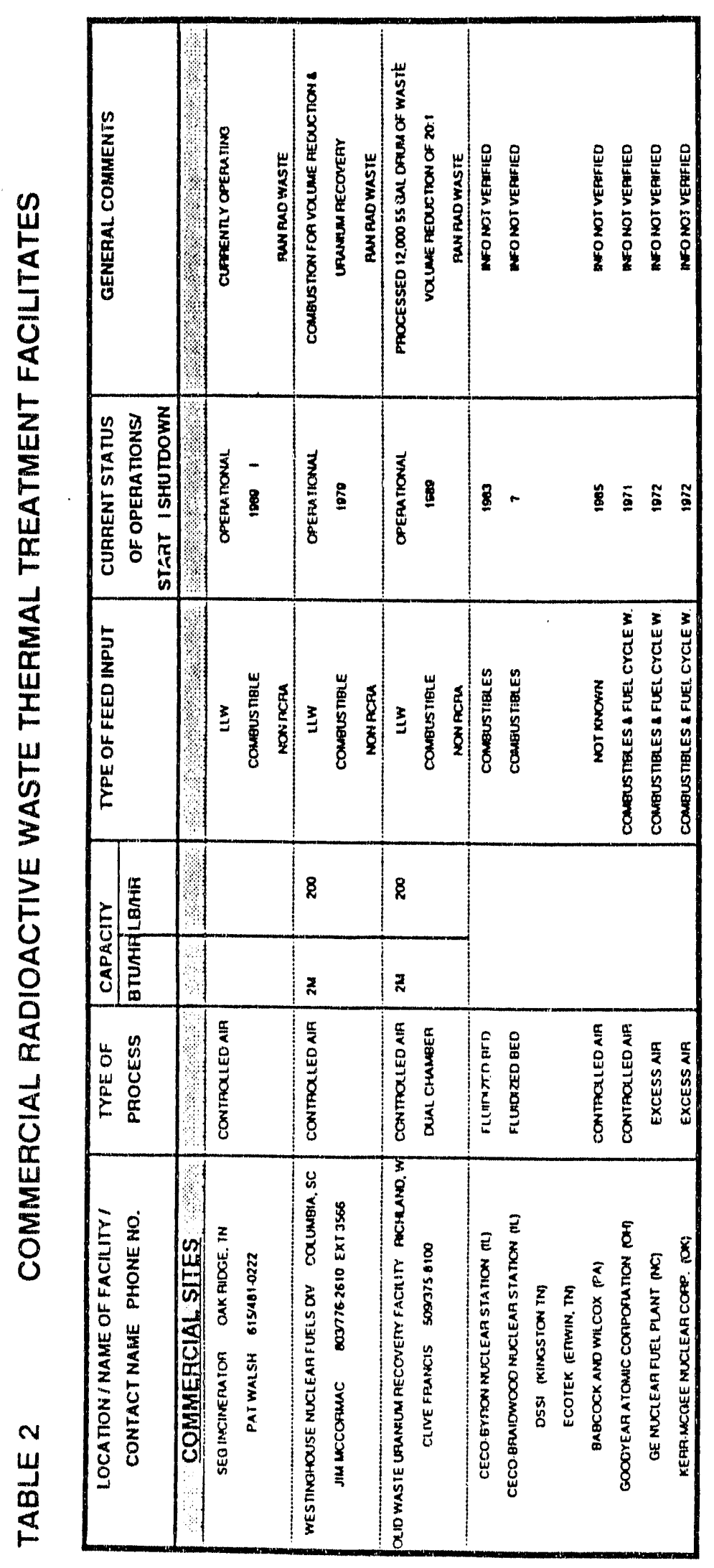




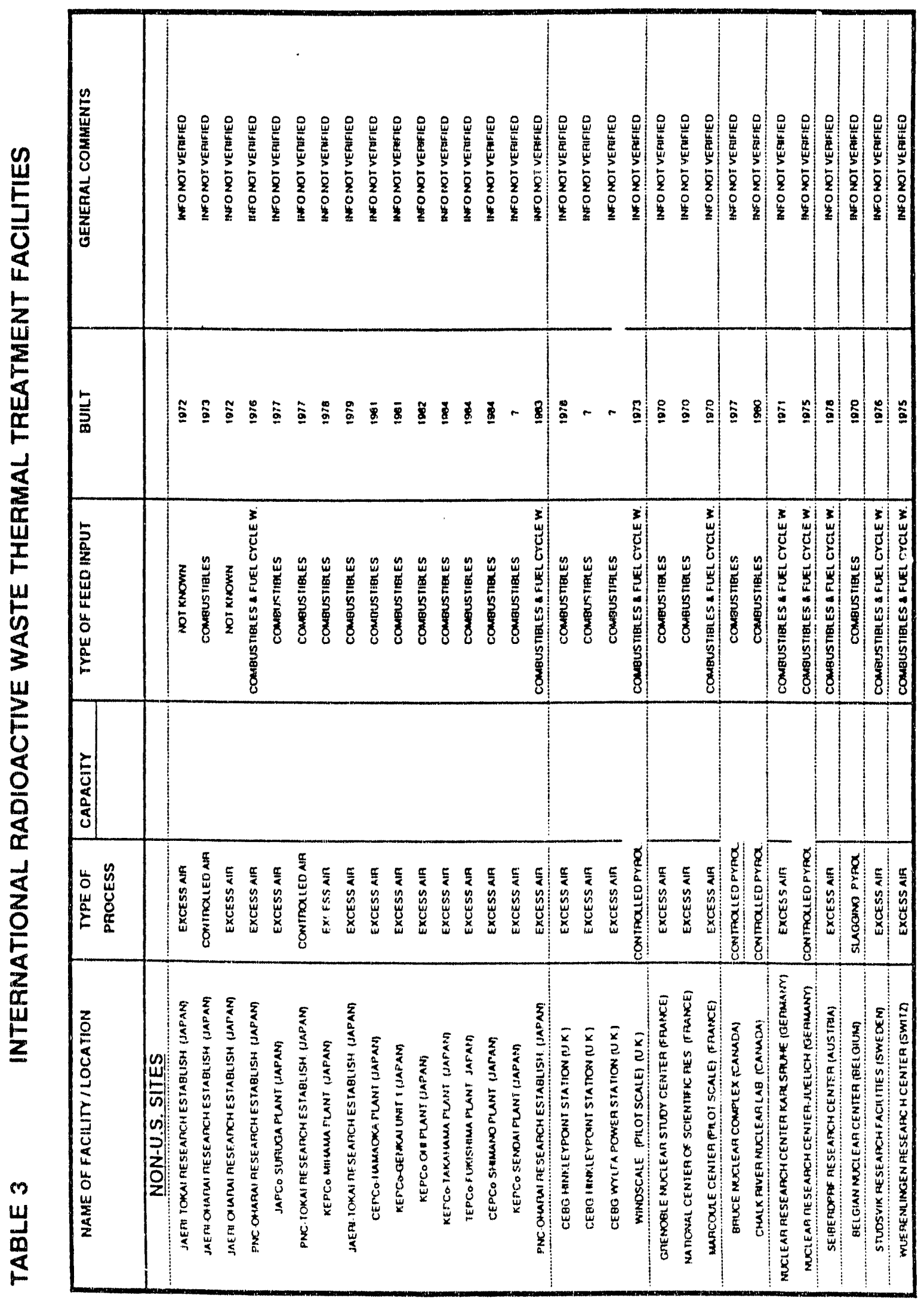


Table 4. Summary of planned DOE thermal treatment projects.

\begin{tabular}{llll}
\hline Technology type & Location & Waste type & Project statusi \\
\hline Vitrification & & & \\
Joule meiter & HANFORD & HLW & Title design \\
Microwave melter & LANL & Mixed TRU & Concept \\
General & Mixed LLW & \\
Incineration & HLW & Concept \\
Rotary kiln & & & \\
Controlled air & SRS & Mixed LLW & NEPA revicw \\
Not defined & LANL & Mixed LLW & Concept \\
TBD & & & \\
TBD & INEL & Mixed TRU & Concept \\
& INEL & Mixed LLW & Concept
\end{tabular}

a. A planned facility is one which may be in the conceptual stage or through title design, and which is not constructed.

Table 5 provides a summary of constructed DOE thermal facilities by technology type. A constructed facility is defined as one that is under construction, in startup, in operation, in standby,or shutdown. There are 21 DOE thermal facilities that have been constructed, 13 of which have processed radioactive waste.

Of the 21 constructed facilities on DOE sites, only two are in operation: the INEL calciner facility and the K-25 at Oak Ridge low-level mixed waste rotary kiln incinerator. Four of the 21 are in the construction and start-up phase. Three of the four will process HLW using joule-heated melter technology. These facilities should be entering the operational mode in the near future.

Fifteen of the 21 facilities have been shut down; four, which were previously operational, are now in a temporary shuldown. The reason these four facilities have been idled is to upgrade their equipment, facility, or documentation. These facilities are scheduled to be operational and resume treatment of radioactive waste in the near future. Eleven of the 21 facilities have been permanently shut down, including five that never processed any radioactive waste. 
Table 5. Summary of constructed DOE thermal facilities. ${ }^{a}$

\begin{tabular}{|c|c|c|c|c|c|c|}
\hline \multirow[b]{2}{*}{ 'Technology } & \multirow{2}{*}{$\begin{array}{c}\text { Total } \\
\text { number } \\
\text { constructed }\end{array}$} & \multirow{2}{*}{$\begin{array}{l}\text { Number } \\
\text { processing } \\
\text { radioactive }\end{array}$} & \multicolumn{4}{|c|}{ Status } \\
\hline & & & Shutdown & Standby & $\begin{array}{c}\text { Under } \\
\text { construction }\end{array}$ & $\begin{array}{c}\text { In } \\
\text { operation }\end{array}$ \\
\hline \multicolumn{7}{|l|}{ Vitrification } \\
\hline Joule melter & 3 & 0 & & & 3 & \\
\hline \multicolumn{7}{|l|}{ Incineration } \\
\hline Controlled air & 7 & 5 & 4 & 2 & 1 & \\
\hline Rotary kilni & 3 & 1 & 2 & & & 1 \\
\hline Fluidized bed & 2 & 2 & 1 & 1 & & \\
\hline Cyclone & 1 & 1 & 1 & & & \\
\hline Stationary grate & 1 & 1 & & 1 & & \\
\hline Agitated hearth & 1 & 0 & 1 & & & \\
\hline Batch combustor & 1 & 1 & 1 & & & \\
\hline Calcination & 2 & 2 & 1 & & & 1 \\
\hline Total & 21 & 13 & 11 & 4 & 4 & 2 \\
\hline
\end{tabular}

a. A "constructed" facility is one in construction, in startup, in operation, in standby, or shutdown mode.

The reasons for shutdown, permanent or temporary, of constructed facilities by technology are shown in Table 6. The reasons are divided into four basic categories: (1) design deficiencies, (2) public pressure, (3) documentation upgrades, and (4) the facility is no longer needed. Design deficiencies appear as the foremost cause of problems, followed by pressure from public interest groups or the public in general. That so many of these facilities had design deficiencies sufficient to require shutdown, indicates that an incineration process is technically complex. For some examples of the design deficiency problems, see Section 3.3.1. It also indicates that significant details could be learned from these failed facilities to assist in the design of new facilitics. 
Table 6. Reasons for shut down or standby of constructed facilities.

\begin{tabular}{|c|c|c|c|c|c|c|}
\hline \multirow[b]{2}{*}{ Technology } & \multicolumn{3}{|c|}{ Shutdown (no planned restart) } & \multicolumn{3}{|c|}{ Standhy (planned restart) } \\
\hline & Design deficiency & $\begin{array}{l}\text { Public } \\
\text { pressure }\end{array}$ & $\begin{array}{l}\text { No longer } \\
\text { needed }\end{array}$ & Design deficiency & $\begin{array}{l}\text { Public } \\
\text { pressure }\end{array}$ & $\begin{array}{c}\text { Documentation } \\
\text { upgrade }\end{array}$ \\
\hline Controlled air & ORNL, SRS, SRS & & & & & INEL, LANL. \\
\hline Rotary kiln & INEL, RFP & & & & & \\
\hline Fluidized bed & & RFP & & & RFP & \\
\hline Cyclone & $\mathrm{ML}$ & & & & & \\
\hline Stationary Graie & & & & RFP & & \\
\hline Agitated hearth & RFP & & & & & \\
\hline B,tch combustor & & L.ANL & & & & \\
\hline Ca'sination & & & HFS & & & \\
\hline
\end{tabular}




\section{EXPERIENCE FROM SELECTED THERMAL. PROCESSING FACILITIES}

From the 21 projects that have been constructed within the DCE, 9 thermal facilities were selected for further evaluation. The intent of this facet of the study was to provide an initial examination of experience available from the facilities that could be useful in the development of future systems for INEL needs. Table 7 lists the selected facilitics by location, name, type of technology, and the criteria for facility selection. The following criteria were used to select thermal treatment facilities:

a. Whether the thermal technology is a likely candidate for planned or future thermal options

b. Whether the waste type requirements were similar to INEL waste requirements

c. Whether there were aspects of the facility that may be applicable to present needs and requirements.

One commercial radioactive waste processing facility, SEG, Oak Ridge, Tennessec, was cvaluated as part of this exercise. This facility was included primarily because of its apparent continuing success in processing LLW.

The survey involved contacting individual(s) familiar with each selected facility. A survey form was sent to each person, and interviews were conducted to obtain and verify the information necessary to complete this study. Because the scope of this study was limited to an initial screening of experience for the selected facilities, generally only one person was contacted who could provide a reasonable level of detailed information on the facility. Therefore, although believed representative, this data must be considered preliminary in nature and is by no means exhaustive.

Detailed status reports summarizing the data collected on each of the facilities are provicied in Appendices. This information includes a description of the facility, the current status of the system and permits, the problems encountered, the resolutions to those problems (when known), and general comments from the contact person. The following sections summarize some of the main findings from examination of the compiled facility experience.

\subsection{Summary of Facility Problem Areas}

No one functional area predominated in the number, type, or severity of problems encountered for the incinerators studied. Therefore, to increase the potential for suceess, careful consideration is required for all aspects of the incineration process, from waste feed through offgas relcase. Careful 
Table 7. Selected thermal processing facilities.

Idaho National Engineering

Laboratory (INEL)

Process Experimental Pilot

Plant (PREPP)

Rotary kiln $\quad a, b, c$

Waste Experimental Reduction

Facility (WERF)

Controlled air a,b,c

Los Alamos National Laboratory (LANL)

Controlled Air Incinerator

(CAI) [TA-50-37]

Controlled air a,b,c

Mound Laboratory

Glass melter

Joule melter

a

Oak Ridge National Laboratory (ORNL)

TSCA incinerator

Rotary kiln

$a, b, c$

Rocky Flats Plant (RFY)

Fluidized bed incinerator

(FBI) Demonstration

Fluidized bed

b,c

Savannah River Site (SRS)

Beta-Gamma incincrator (BGI)

Controlled air

$a, b, c$

Consolidated incineration

Facility (CIF)

Controlled air

$a, c$

Defense waste processing

Facility (DWPF)

Joule melter

a

Commercial

Scientific Ecology Group (SEG) Incinerator

Controlled air

$a, b, c$ 
selection of construction materials (i.e., high alloy metals and high alumira refractory) is as important as selection of functional system components.

In addition to individual facility problems, common problems exist in facility designs and operations. Each of these problem areas needs particular attention in the design of a new thermal facility to avoid repeating the deficiencies.

\subsubsection{Technical Problems}

\section{Waste Feed Systems}

- The INEL PREPP and Rocky Flats FBI incinerators experienced problems with long stringy material passing through their shredders and causing feed problems.

- The PREPP inertial feed conveyor had difficulty transporting wet sludges to the feed hopper.

- The PREPP tractor-operated leed hopper had high maintenance requirements and the feed hopper enclosure tended to fill with dust and smoke from the kiln, impairing visual operation.

- Stringy plastic olten fouled the FBI air classifier system.

- The FBI feed hopper for the screw conveyor to the combustion chamber had bridging problems. The screw conveyor jarnmed on dense feed material.

- To decrease maintenance, the LANL CAI feed drive was changed from chain/sprocket to hydraulic.

\section{Incincrator}

- PREPP experienced very carly kiln rotary scal failures at operating temperatures, which led to excessive air leakage into the kiln and excessive seal drag on the kiln drive.

- The INEL WERF incinerator could not attain design feed rates because of high temperatures caused by ash pile carbon burnout. Attempts to increase the feed rate by "choking" the incinerator resulted in incomplete combustion and malting of plastics with accompanying high-waste agglomeration.

- The CAI, WERF, and SEG incincrators were changed to higher alumina castable refractory to combit crosion/slag attack problems. 
- The Mound glass melter experienced problems with short life and diflicult change-out of electrodes. Thicy also had problems with draining the glass from the melter.

- The Savannah River BGI incinerator experienced several problems related to primary chamber pressure:

- The chamber pressure sensor was not sufficientiy sensitive to accurately detect pressure excursions slightly above atmospheric.

- The location of the system pressure control vi.ive was inappropriate for acceptable feedback control.

- Pressure excursions in the primary chamber resulted in leakage of combustible gases into the adjacent ram feed housing, resulting in an explosion.

\section{Offgas Treatment Systems}

- PREPP experienced rapid loading up of their HEPA filters because of salt and particulate carryover from the wet scrubbing system.

- PREPP had to redesign its scrub solution system to handle larger-than-anticipated particulate that settled out in the hold-up tank and to resolve sludge handling problems.

- WERF experienced fouling and corrosion problems in their air-to-gas heat exchanger.

- The fiberglass fan blades of the Oak Ridge TSCA incinerator were changed so metal draft after catastrophic failure of the fiberglass fan blades.

- The FBI's catalytic oxidation (afterburner) unit suffered from catalyst entrainment problems, which required redesign of the tlow pattern.

- The FBI employed an untested design in the water spray heat removal system for the catalytic oxidation unit that required major modifications after several incinerator runs.

- BGI, SEG. and WERF have all struggled with various baghouse bag fouling problems.

- SEG's boiler has experienced tube fouling problems and has temperature limitations that restric maximum oflgas cemperature.

- The BGI was shut down primarily because of offgas system corrosion problems created by improper construction materials and inadequate acid gas scrubbing. 
Ash Transport/Handling

- WERF and CAI have had problems with plugging of their vacuum pneumatic ash transfer systems. CAl system was replaced with a gravity drop system.

- The PREPP inertial ash conveyor system bellows fatigued and failed because of ash filling the bellows and restricting its movement.

- The PREPP had to redesign ash transport systems to minimize ash and dust accumulation areas to ensure criticality control (SAR).

- WERF had to modify its bottom ash handling system to remove the binding-prone clamshell doors that dumped to the ash drumming system. They alio had to install a shear shredder to reduce clinker size for drumming and solidification operations.

- SEG had to enhance its waste separation operation to preclude aiamp metal that binds up its ash transfer system.

Instrumentation and Control Systems

- PREPP added additional diesel backup power capability and altered its instrumentation and control system after a primary power system fuse failure resulted in scrub solution flooding of the secondary combustion chamber (SCC).

- WERF and CAI have upgraded their control systems to PC-based programmable logic control systems to enhance process control.

- The BGI concluded that it needed a remote set of emergency shutdown controls in the event of an evacuation emergency.

- SEG experienced instrumentation and other sensitive component failures because of chronic high temperatures in the incinerator building. Its offgas monitors also required high maintenance, which was somewhat mitigated by reducing building temperatures.

Other Technical

- The BGI suffered from poor access to major components for maintenance or removal and from the lack of built-in lifting capability for these lunctions.

- The PREPP criticality control system was based on administrative controls but current requirements need more rigorous engineered system control. 


\subsubsection{Regulatory/Public Probiems}

- The CAI was shut down lier system upgrades. A state moratorium on incineration and heavy local opposition to incineration have delayed startup. The moratorium expired in the fall of 1990. Now NEPA is the major impediment.

- The FBI was shut down because of active local opposition and accompanying reaction of state regulators.

- The LLNL controlled air incinerator was shut down after being denied an operating permit by the state following two trial burns. The incinerator and a proposed new incinerator received heavy public opposition, causing plans for the new incinerator to be scrapped.

\subsubsection{Institutional Problems}

- PREPP was shut down because of its incompatibility with the current requirement of DOE order 6420.1A, General Design Criteria.

- WERF was shut down until environmental ar d safety documentation can be upgraded.

\subsection{Comparisons}

- The K-25 TSCA incinerator, which was designed primarily for depleted uranium contaminated waste, is the only DOE radioactive waste incinerator studied not using HEPA filtration.

- The majority of offgas treatment systems apparently use adiabatic saturation cooling (SRS, LANL, ORNL, Mound, PREPP) more than totally dry cooling and filtration (WERF), reflecting a widespread need to process halogenated wastes. 


\section{SUMMARY}

There is a wealth of experience based information potentially available within the DOE system on thermal processing technologies that could be documented and examined. Of the 17 thermal units built and operated for DOE only two are operational; four are in standby and may operate again, and 11 were shut down because of design deficiencies or public pressure. Initial evaluation of some of these facilities has identified a number of areas where common problems among facilities exist. It is recommended that future efforts pursuing thermal treatment of radioactive waste examine, in detail, the efforts and experiences of these previous projects. Additionally, commercial and international radioactive waste treatment facilities may provide another valuable source of information.

A large body of implicit knowledge exists within the DOE system on incineration based technologies, because many of these types of processes have been designed, constructed, and operated. The experience base for melter technologies is more limited within the system with emphasis on JHM for HLW, but some significant work has been done at PNL, SRS, and Mound. The relatively recent entry of most commercial melter technologies into the hazardous and radioactive waste processing applications arena means that considerable evaluation and demonstration work is needed to properly assess and develop their capability. Some initial assessment work has been performed and is reported. 2,7

A general comment is in order regarding the various technical, institutional, and regulatory problems described for each of the 10 facilities studied in detail. The level of investigation allowed by the intentionally limited scope of this initial survey study was not adequate to provide a comprehensive assessment of the facilities. Therefore, the number of problems listed should not be interpreted as a measure of the facility's suceess or lack thereof. In most cases if a large number of problems are discussed, it reflects the fact that a good source (or sources) of information was uncovered. Conversely, if lew problems are discussed, it may only mean (a) the contacts were not intimately familiar with the lacilities, (b) the contacts did not have the time to respond comprehensively, or (c) the problems that the facilities had were not well documented. Furthermore, the fact that problems are highlighted more than suceesses does not necessarily mean that the experiences are mostly negative. The focus of this initial survey was upon problems experienced.

It should be noted that there have been some very successful DOE radioactive waste incincration experiences. The LANL. CAI wats a highly suceessful research tool that established at good data base on radioactive waste incineration for many of the follow-on units. The CAl has been retrofitted with state-of-the-art equipment to assume a mission as a production treatment facility, if local politics allow its restart. The INEL WERF incinerator had a run of five to six years of suceessful production operations and at the same time maintained an impeccable appearance and sately record, which matde it a showease for the DOE. Its current shutdown status reflects a need to bring its sately and environmental documentation into conformance with current requirements. 
Examination of successful DOE incineration projects reveals that when experienced engineers design an incineration process, oversec its construction and startup, and continue to troubleshoot, the process should have a history of superior performance. The experience of the staff contributing to a successful system is invaluable.

While a substantial design, permitting, and operating experience base exists within the DOE system for incineration based technologies, much of this experience is not shared and a reliable single source of data on these experiences is not available. A valuable tool for developers of thermal systems would be a comprehensive data base that contains the pertinent technical literature, design, and operating experiences of previous developers and operators of radiological thermal treatment systems. This experience base for thermal treatment technologies could be even more extensive if commercial hazardous waste facilities were considered. 


\section{REFERENCES}

1. J. Mayberry, W. Quapp, F. Feizollahi et al., Preliminary Systems Designs Study Assessment Report Vol II (main report), EGG-WTD-9594-2, September 1991.

2. G. Anderson and R. Geimer et al, An Assessment of Incinerations and Melting Treatment Technologies for Application to RWMC Buried Waste, EGG-WTD-10().35, February 1992.

3. R. Gillins et al., Thermal Technologies for RWMC Wastes, EGG-WTD-9449, January 1991.

4. H.M. r reeman et. al., "Thermal Destruction of Hazardous Waste - A State-of-the-Art Review," Journal of Hazardous Materials, 14, 1987, pp 103-117.

5. Ralph A. Koenig "Summary of Radioactive and Mixed Waste Incineration Technologies Within the Department of Energy Nuclear Weapons Complex," Prepared for Congress of the U.S. Office of Technology Assessment, June 10, 1990.

6. F. O. Farinoso and R. B. Wilson, 1983, "Radwaste Incinerator Experience," Research Project 1557-4, EPRI NP-3250.

7. A. Donaldson, R. Capendo, and G. Anderson, Melter Development Needs Assessment for RWMC Buried Waste, EGG-WTD-9911, February 1992. 
Appendix A

Idaho National Engineering Laboratory (INEL) 
A-2 


\section{Appendix A}

\section{Idaho National Engineering Laboratory}

\section{A-1. FACILITY DESCRIPTION}

PREPP is a rotary kiln incineration facility located at the INEL. PREPP was originally designed to process TRU-contaminated waste that could not be certified for shipment to WIPP. The mission of PREPP was later changed to processing reclassified LLW.

Incoming waste is moved into the shredder room where it is fed into a two shaft, low-speed shredder which opens the waste containers. Shredded waste falls into an inertial drive vibratory conveyor, which transfers it into a kiln feed hopper. When the tractor driven feed hopper is filled and the kiln is ready to be charged, a feed gate in the kiln firing hood opens and the hopper is shuttled into the kiln, rotated 180 degrees to dump the waste. The kiln operates at temperatures between 1600 and $1800^{\circ} \mathrm{F}$. Hot ash exiting the kiln falls into an inertial drive ash conveyor located beneath the secondary combustion chamber (SCC). This conveyor is integrally cooled with air and water and serves to both move the ash away from the kiln and cool it during the transport. The ash is cooled to approximately $180^{\circ} \mathrm{F}$ before reaching a rotary trommel. The trommel, or rotating screen, separates fine ash from the coarse and the coarse ash moves on to a drum fill enclosure. The fine ash is pneumatically transferred to blenders where it is stored until used in the grouting operation. Coarse ash is hand-raked into drums and grouted in the drum fill enclosure.

Combustion gases from the kiln flow into a SCC where they are heated to temperatures ranging from 2000 to $2200^{\circ} \mathrm{F}$, with a minimum retention time of two sec. The gases are then treated in a wet offgas system that consists of a quencher, venturi scrubber, entrainment eliminator, mist eliminator, reheaters, prefilters, and high efficiency particulate air (HEPA) filters. Fans downstream of the HEPA filters maintain a negative pressure in the kiln and SCC.

Scrub solution from the venturi scrubber, buffered with sodium carbonate, is recycled and used for quenching and scrubbing. Scrub solution regeneration is accomplished with makeup to replace water lost in the treatment systems "evaporation) and by using a scrub solution in the grout mixture. Particulates are removed from the scrub solution using a cross-flow filter system. The resulting concentrated sludge is used in the grouting process. 


\section{A-1.1 Specifications}

Manufacturer

Design thermal capacity

Throughput capacity

Feed input

Secondary waste streams

Destination of output
Vulcan

8.5 M Btu/hr

$600 \mathrm{lb} / \mathrm{hr}$

LLW mixed and TRU mixed solid and liquid waste (no tests were made with radioactive or hazardous material)

Scrub solutions and HEPA filters

TRU waste destined for WIPP; LLW destination unknown.

\section{A-2. CURRENT STATUS OF SYSTEM}

PREPP has been placed in standby status pending a review of potential uses.

\section{A-3. CURRENT STATUS OF PERMITS}

RCRA

TSCA

Clcan Air (NESHAPs)

State Air Quality

Local Air Quality
Interim status assumed; preparing Part B application when facility was shut down

Not required (NR) - there were no plans for TSCA permits

Not obtained - a drafted NESHAPs permit was submitted to DOE-ID only

Not obtained - a dralted air quality permit was submitted to DOE-ID only

NR

\section{A-4. PUBLIC INVOLVEMENT/PERCEPTION}

The public was minimally involved in construction or startup operations. No public meetings were held on the incinerator and the general public raised no concerns. A small local environmental group included the incinerator in its list of facilities of all kinds at the site for which it raised environmental and safety questions in a general oppositional tactic. PREPP's remote location positively influences public opinion. 


\section{A-5 PROBLEMS/RESOLUTIONS}

\section{A-5.1 Shredder}

Long narrow materials such as the banding clamps used on metal drums and long sections of small diameter pipe would stand on end and fall between the shredder teeth and spacers. This was solved by installing a remotely operated secondary grapple designed to remove the long items from the waste stream in the conveyor beneath the shredder.

Periodic retipping of the shredder teeth is required. In a radioactive environment, particularly an alpha-contaminated cell, this is diflicult, costly, and time consuming. A partial solution is to use a high grade steel for the teeth' in increase tip life.

\section{A-5.2 Kiln Seals}

The kiln seals supplied with the kiln were inadequate and had to be replaced. The large rotary triple seals custom designed for PREPP failed on initial heatup, allowing excessive air leakage into the kiln, which prevented attainment of desired kiln temperatures, and caused excess drag on the seals, which overloaded the kiln drive system. The seals were redesigned and cold tested, but no hot (thermal) testing has been performed to validate the fix.

\section{A-5.3 Ash Handling System}

The inertial conveyor in the ash discharge system required constant fine-tuning of the cooling air and hanger rods. The cooling of the conveyor was marginal.

The conveyor used a series of metal bellows $t 0$ isolate the reciprocal conveyor motion from the stationary trommel, SCC, and drive system containment penetration. The bellows action during conveyor operation created a pumping action that caused fine ash to be carricd back into the bellows. The lower convolute of the bellows would fill with ash and would pack to the point where the bellows action became restricted. This led to early fatigue and failure of the bellows. The proposed solution to the problem was to design a rotary discharge conveyor system to replace the inertial conveyor.

\section{A-5.4 Offgas System}

The main operating problem encountered with the offgas system was rapid loading of the HEPA filters. Most of the particulate accumulating on the filters was salt carried over from the scrubber and particularly the quencher. The solution to this problem was first to introduce clean scrub solution makeup into the system in the form of a very fine mist in the crossover duct between the SCC and the quencher vessel. The clean mist would perform the initial high temperature quench, 
thereby minimizing the cooling required with salty scrub solution and minimizing the particulate generation. The second solution was to use a high efficiency mist eliminator in place of the current unit. The improved version used the mist eliminator as a self-eleaning prefilter, allowing the moisture removed from the gas to wash the soluble particulate from the mist eliminator pads. The third solution was to use prefilters that, upon change-oul, would not require the performance verification test associated with changing out the ecrtified HEPA filters. The results of these changes have not been verified because the unit was shut down before additional testing could be performed.

\section{A-5.5 Scrub Solution System}

The scrub solution system could not accommodate particulate removed from the gas stream. The scrub solution from the quencher, scrubber, and entrainment and mist eliminators drain to the surge recycle tank, a conventional horizontal vessel that was constantly agitated. Despite this constant agitation, the particulate settled to the bottom of the tank and formed a heavy sludge. This sludge buildup continued until it started covering up the pump suction screens. The system would then be shut down, drained, and the sludge physically removed by shoveling it out. The cross-1low filter system, designed to remove particulate from the scrub solution, did not perform well. The blowback system for cleaning the filters did not work as designed and the filter medium slowly became irreversitly plugged. The solution to the problem was to redesign the scrub solution system. The surge recycle tank was changed to a vertical, conical bottom tank and the pumps were located outside

the tank for easier maintenance. The cross-flow filter system was replaced by three hydrocyclones with sludge tanks with service to be rotated among the units. This modification was not completed before shutdown.

\section{A-5.6 Criticality Monitoring System}

The criticality control system was based on administrative controls supported by a system of surveying, monitoring, and record keeping. The current requirements require a more rigorous control system, for example an engineered system. The solution to the problem was to reassess the criticality control plan using PRA technigues and conduct testing of critical areas and components to support the PRA and modily for an engineered system. PREPP was inactivated before the solution was implemented.

\section{A-5.7 Feed System}

The inertial drive conveyor worked well for transporting all waste materials except wet sludges. Wet sludge stuck to the conveyor pan and drier sludge tended to form into balls that would roll with the conveyor movement but obtained little net movenent. The solution to the problem was to feed the wet sludge along with dry material so the dry material would carry the sludge with it on the inertial drive conveyor. 
The tractor-operated feed hopper required considerable maintenance. Occasionally, spillage of waste from the hopper was sufficien io cause interference with the tractor drive system. In addition, the correct air flow balance between the kiln and feed enclosure was difficult to maintain. Dust and smoke in the feed enclosure impaired visual observation of the hopper fill operation. The batch feed operation made the combustion process in the kiln transient with the control system, automatically compensating for the dynamics of the system by adding extra combustion air as the waste was dumped into the kiln. This caused continual thermal cycling. The projected solution was to replace the feed hopper with a tapered auger feed system.

\section{A-5.8 Electrical/Control System}

A fuse failure in the incoming electrical distribution system created a chain of events that allowed quench water to overflow from the wet offgas system into the incinerator SCC. The electrical and plant instrumentation and control systerns were redesigned to increase system reliability. A diesel generator to provide additional backup power also was installed.

\section{A-6 GENERAL COMMENTS}

With proper modifications the PREPP rotary kiln has good potential, if not for operation, at least as a proof of principle unit.

\section{A-7. BIBLIOGRAPHY}

Ayers, A. L., Jr., et al, "Offgas System Particulate Cleaning Test and Evaluation for the Process Experimental Pilot Plant," Incineration '90 Conference, San Diego, March 1990.

Ball, Lawrence J., "PREPP Operating Experience and Status," EG\&G Idaho Inc., October 1989.

Drexler, R. L., "PREPP Rotary Kiln Seals - Problem and Resolution," Incineration '90 Conference, San Diego, CA, March 1990.

Halford, V. E., et al, "Redesign of the PREPP Feed, Ash Discharge, and Sludge Handling Systems," Incineration ' 90 Conference, San Diego, CA, March 1990. 
Appendix B

Waste Experimental Reduction Facility (WERF) 


\section{Appendix B}

\section{Waste Experimental Reduction Facility (WERF)}

\section{B-1. FACILITY DESCRIPTION}

The Waste Expeimental Reduction Facility (WERF) is a versatile LLW treatment facility that has been in operation at the INEL since 1982. The facility was designed to reduce the volume and entance the form of INEL LLW disposed at the RWMC and to treat radioactive mixed waste (MW). WERF employs metal sizing, metal melting, compaction, incineration, and solidification processes. Incineration is the most effective of the WERF treatment processes, effecting 250:1 volume reduction of combustible solid waste while detoxifying and homogenizing solid waste into a form suitable for stabilization by solidification. The incinerator has been processing beta/gamma LLW since September 1984. The incinerator is permitted to process MW under Resource Conservation and Recovery Act (RCRA) interim status.

The WERF incinerator is a dual chamber controlled-air unit. Solid LLW and MW are accepted at the facility in $\angle \mathrm{ft} \times 2 \mathrm{ft} \times 2 \mathrm{ft}$ cardboard boxes. The boxes are fed to the incinerator by gravity feed through a triple door air-lock arrangement. Boxes are conveyed to the feeder through a portal radiation monitor, an $x$-ray unit, and a load cell for weighing each box to monitor throughput rates.

Liquid LLW and MW are aceepted at the facility in 55-gal drums. These wastes are fed to the incinerator via a liquid feed system that extracts the waste from the drums and pumps it to a $T$. Thermal LV-1 vortex burner in the primary chamber.

Offigas from the secondary chamber enters the offigas system at temperatures ranging from 1800 (1) $2(m))^{\circ} \mathrm{F}$. The incinerator offgas system is a dry mechanical filtering system. The gases are first diluted with incinerator room air $\mathrm{to}$ cool them $\mathrm{to}<1200^{\circ} \mathrm{F}$. The gas then passes through a shell-andtube gas to air heat exchanger to reduce the temperature to approximately $750^{\circ} \mathrm{F}$. A second air dilution using building air then reduces the temperature to about $4(K)^{\circ} \mathrm{F}$. The gas then passes through iwo parallel baghouses, roughing filters, and a single stage of HEPA filters for particulate removal. Offgas is drawn through the syste $m$ by parallel induced draft fans and exhausted through a 49-fi stack.

The use of a dry offgas system requires that the waste feed be restricted in contemt of acid forming materials such as chlorine to minimize corrosion problems. Administrative controls at the generator locations and periodic waste inspections at WERF accomplish this.

From the baghouse hoppers. incinerator tlash is pneumatically transferred to an ash collection/handling system. The ash is then transferred to 71 -gal square drums for stabilization. The 
incinerator bottom ash is pushed into a collection hopper by the action of a hearth ash "ram." In the hopper, the ash is cooled for transfer through a shear shredder into 71 -gal square drums for stabilization. The shear shredder serves to meter ash into the drums and reduce the size of ash clinkers for stabilization.

Drummed ash is stabilized by solidifying it with Portland ecment. Cement and water are thoroughly mixed with the ash in the drum. The final product, resembling a concrete block, is a high integrity waste form containing no Iree liquids or dispersible fines. In addition, the leachability of the hazardous heavy metals from the ash is reduced sufficiently to pass EPA leachability criteria. The solidified ash from the WERF is shipped to the INEL's RWMC for disposal as LLW.

\title{
B-1.1 Specifications
}

\author{
Manufacturer (Incinerator) Ecolaire (now Joy Technology) \\ Thermal capacity \\ 5 million Btu/hr \\ Throughput capacity \\ $400 \mathrm{lb} / \mathrm{hr}$ of $12,0(\mathrm{k}) \mathrm{Btu} / \mathrm{lb}$ waste \\ Feed input \\ Nonchlorinated, solid and liquid, combustible \\ LLW mixed and LLW \\ Secondary waste streams \\ HEPA filters and baghouse bags \\ Destination of output \\ RWMC (LLW) or mixed waste disposal facility
}

\section{B-2. CURRENT STATUS OF SYSTEM}

The WERF incinerator has not been operated since February of 1991. It was shut down to update its environmental and safety documentation. It is scheduled to start up again in late 1991.

\section{B-3. CURRENT STATUS OF PERMITS}

$\begin{array}{ll}\text { RCRA } & \begin{array}{l}\text { Interim status; Part B application submitted } \\ \text { and trial burn completed }\end{array} \\ \text { TSCA } & \text { NR/Not planned } \\ \text { Clean Air (NESHAPS) } & \text { Yes } \\ \text { State Air Quality } & \text { Operating under a Permit } w \text { Construct }\end{array}$




\section{Local Air Quality $\quad$ NR}

\section{B-4. PUBLIC INVOLVEMENT/PERCEPTION}

The WERF has not undergone public hearings associated with permitting. Therefore, public perception can only be estimated. Articles regarding the WERF incineration facility have been published in the Idaho Falls, Idaho, newspaper including some front page stories. Press coverage has not resulted in negative feedback by the local community. A small local environmental group included the incinerator in its list of facilities of all kinds across the Site for which it raised environmental and safety questions in a general oppositional tactic. The WERF's remote location is a positive factor that influences public opinion.

\section{B-5. PROBLEMS/RESOLUTIONS}

\section{B-5.1 Incinerator}

The incinerator thermal capacity is rated at $5 \mathrm{MMBtu} / \mathrm{hr}$, which was expected to translate into an average feed rate of $400 \mathrm{lb} / \mathrm{hr}$ (based on 12,000$) \mathrm{Btu} / \mathrm{lb}$ waste). However, after feeding about 1,500 Ib of waste at a feed rate of 400$) \mathrm{lb} / \mathrm{hr}$, the buildup of temperatures in the primary chamber becomes excessive because of the buildup and burnout of fixed carbon on the hearth. To remedy the problem, feed to the incine ator has to be interrupted long enough to allow the fixed carbon to burn off. After the burnout, feeding is resumed at the rated capacity. The result is an overall average feedrate of around $200 \mathrm{lb} / \mathrm{hr}$ instead of the $400 \mathrm{lb} / \mathrm{hr}$ that was expected.

An inilial attempt to increase the feed rate involved force-feeding (or choking) of the primary chamber with the waste, which quenched the chamber temperature but provided higher piles of partially combusted ash that still had to be burned out later. The lower temperatures under the higher ash piles caused waste plastics to melt but not combust, forming pools of molten plastic on the hearth under the ash. This molten plastic, with the accompanying absorbed ash and small solids, was pulled back into the ash ram housing by the retracting hearth ram, filling the housing voids and setting up as a hard, agglomerated mass which had to be chipped out. The solution was to abandon force-feeding of waste.

\section{B-5.2 Ash Handling}

The original ash handling system for transferring ash from the primary chamber to drums used clam shell gates. Because of the formation of large (up to 2 ft across) clinkers, the metering of ash into a crrum was difficult. Clinkers would frequently get caught in the clamshell doors, thereby preventing a complete shutoff of the flow of ash into a drum and complicating replacement of drums. To remedy the problem, a new ash handling system was installed using a shear shredder to meter and size reduce the ash. The shear shredder replaced the clam shell doors in the metering of ash and 
reduces the size of elinkers $t 0$ approximately 2 in. for improved solidification. This solution has been very effective. 


\section{B-5.3 Heat Exchanger}

The heat exchanger in the incinerator offgas system has had problems with corrosion and with deposits leading to increased pressure differential. The offgas passes through the tube side of the shell and tube heat exchanger. Periodically, these tubes are manually cleaned of ash and other deposits from the hot end (inlet end). However, molten materials carried over from the incinerator condensed on the cold (discharge) end of the heat exchanger cannot be easily removed. These materials are deposited as a hard ceramic coating that has to be chipped away. In addition, the hot corrosive conditions that the heat exchanger is exposed to has led to the separation of the tubes from the shell and tube failure within the first foot of tube. The only resolution to this problem to date has been repairs, when possible. The heat exchanger was recently changed out because it was determined that the damage was too extensive to repair.

A spray dryer absorber (SDA) system has been designed and installed in parallel with the heat exchanger. When this system becomes operational, it will allow feeding of chlorinated wastes and also will minimize or eliminate the heat exchanger problems.

\section{B-5.4 Baghouse}

The baghouse has, at times, had pressure differential problems because of the bags becoming coated with a black material with a greasy consistency. This problem was solved by running the baghouse at elevated temperatures $\left(450-490^{\circ} \mathrm{F}\right.$ ) and pulsing down at these temperatures. This dries out the material, and allows it to be pulsed from the bags. The source of the material is still unknown. Since going to Tefaire bags ( $85 \%$ teflon, $15 \%$ fiberglass), blinding wi the bags with small particulate has been a problem. This has lead to an increase in the frequency of bag changeout. The planned solution is to use $100 \%$ fiberglass bags. This process has not been attempted.

The pneumatic transfer line that transfers ash from the baghouse hoppers to the ash handling area has had problems with plugging. This has resulted from ash consistency and from the ash absorbing moisture from the air. The solution to this problem was increasing the diameter of the transfer line and heating the transfer air to approximately $400^{\circ} \mathrm{F}$. This system has not been operated yet, therefore solution effectiveness is unknown.

\section{B-5.5 HEPA Filter Seals}

A liquid silicon was used to seal the original HEPA filters in place. These seals failed prematurely because of what was believed to be the high temperature of the environment. The original liquid silicon was replaced with a blue gel seal, rated for higher temperatures. These seals have been effective so far. 


\section{B-6. GENERAL COMMENTS}

The WERF incinerator has operated very effectively over its life. However, the incincrator has only been operated about 10 days per month during its operating history. It has been found that the system will only operate effectively for about 20 consecutive days of around the clock usage before buildup of a variety of problems require system shutdown. The problems that occur after this amount of time are considered resolvable if operating the incinerator continuously ever became necessary.

\section{B-7. BIBLIOGRAPHY}

Dalton, J. D., "Second Progress Report for the WERF Incinerator," EG\&G Idaho Informal Report No. EGG-WM-8154, June 1988.

Gillins, R. L., et al, "Progress Report on Contaminated Solid Waste Incineration at the Waste Experimental Reduction Facility." INEL Informal Report No. EGG-WM-7162. February 1986.

Gillins, R. L., et al, "Low Level Waste Incineration at the Idaho National Engineering Laboratory," International ANS Conference, New Orleans, LA, June 1985. 


\section{Appendix C}

Los Alamos National Laboratory (LANL) Controlled Air Incinerator (CAI) 
C. 2 


\section{Appendix C}

\section{Los Alamos National Laboratory (LANL) - Controlled Air Incinerator (CAI)}

\section{C-1. FACILITY DESCRIPTION}

The CAI is a dual chamber controlled-air incinerator. Initial combustion takes place in the primary combustion chamber (PCC), which, operates at a temperature of $1400-2000^{\circ} \mathrm{F}$. Solids are fed to the PCC by a RAM feeder mechanism and liquids by a liquid-injection burner capable of firing on natural gas, fuel oil, or liquid waste/fuel blends.

Offgases leaving the PCC pass through a connecting duct to the secondary chamber. The SCC, which operates at $2000-220()^{\circ} \mathrm{F}$, completes the destruction of any volatile organics leaving the primary chamber. The burner in the SCC is fired solely on natural gas. Temperature controllers and safety interlocks ensure that no combustion gas waste from waste is fed into the SCC until the chamber has reached the proper operating temperature.

An offgas treatment and pollution-control system removes particulates and other combustion by-products leaving the SCC. This system consists of the following components:

- Water-Spray Quench Column

- High-Energy Venturi Scrubber

- Packed Column Absorber/Demister

- Offgas Superheater

- Primary HEPA Filters (2 stages in series)

- Carbon Bed Absorber

- Secondary (Final) HEPA Filters

- Scrub Solution Recycie/Cooling System.

\section{C-1.1 Specifications}

Manufacturer

Design thermal capacity

Throughput capacity
Environmental Control Products/

Ecolaire (now Joy Manufacturing)

1.5 M Btu/hr

$125 \mathrm{lb} / \mathrm{hr}$ of solid waste and $200 \mathrm{lb} / \mathrm{hr}$ of liquid waste 
Feed input

Secondary waste streams

Destination of output
TRU/LLW/RCRA solids and liquids

TSCA liquids only

HEPA filters and blowdown liquids

TRU waste will be sent to WIPP; liquids will be sent to the radioactive wastewater treatment facility on site; HEPA filters will require solidification before shipment to WIPP.

\section{C-2. STATUS OF SYSTEM}

The system is shut down pending major modification for production scale operations and lifting of the moratorium on incineration in New Mexico. The moratorium expired in fall of 1990. NEPA documentation and testing are the current delays.

\section{C-3. STATUS OF PERMITS}

CAI currently has a permit for PCB incineration under TSCA and RCRA.

$\begin{array}{ll}\text { RCRA } & \text { Permit in November } 1989 \\ \text { TSCA } & \text { Yes } \\ \text { Clean Air (NESHAPs) } & \text { NR } \\ \text { State Air Quality } & \text { NR } \\ \text { Local Air Quality } & \text { NR }\end{array}$

\section{C-4. PUBLIC INVOLVEMENT/PERCEPTION}

The RCRA Part B permit hearing of 1989 received much press attention and public criticism. This is a politically sensitive issue in New Mexico.

\section{C-5. PROBLEMS/RESOLUTIONS}

\section{C-5.1 Refractory}

The CAI was extensively modified recently to conform to the demands of extended high temperature operation and radioactive containment. The original high alumina refractory on the 
hearth, the sides of the primary chamber, and the ash drop-out pit were replaced with a castable phosphate-bonded chromia-alumina composition. Belore installation of the new refractory, the severely oxidized carbon steel underfire combustion air inlet tubes along the sides of the primary chamber hearth were replaced with Haynes high-temperature Alloy 2.14 material.

\section{C-5.2 Liquid Burner}

A high-intensity vortex liquid burner was installed on the side of the primary chamber. Because this burner has provisions for heat-up and temperature modulation using natural gas or liquid fuel, the original gas-fired burner on the primary chamber was removed. The secondary chamber continues to use a dedicated gas burner for temperature control.

\section{C-5.3 Waste Feed}

All solid waste feed for incineration is prepackanged in $1 \mathrm{ft} \times 1 \mathrm{ft} \times 2 \mathrm{ft}$ cardboard boxes. The CAI's original solid waste feed train consisted of a series of connecting gloveboxes with specific functions: introducrion of waste packages, $X$-ray inspection, gamma assay for radioisotopes, sorting, and finally waste staging prior to ram feeding into the incincrator. The coupling of all these operations into one continuous feed train proved inconvenient. The new design consists of one large solid waste staging glovebox and an introduction air-lock with conveyor. The screening $X$-ray and gamma assay are now separate from the incinerator. Waste packages are loaded from the staging glovebox onto a side ram which transports the package to a position in front of the main ram for feeding into the incinerator primary chamber. The original main ram drive mechanism was based on an electric motor-operated chain on a set of sprockets. This assembly was situated in a housing that was difficult to aceess and had potentially high maintenance requirements. The chain drive mechanism was recently replaced by a single hydraulic cylinder with power pack. The entire hydraulic mechanism is readily accessible for maintenance.

\section{C-5.4 Ash Removal}

Bottom ash removal from the CAI originally involved a short gravity drop-out section at the end of the primary chamber hearth followed by a vacuum transport system. This approach was effective for removal and ransport of normal friable ash, but not for large clinkers or noncombustible objects. Oversized objects tended to plug the transfer lines. This was solved by providing a direct gravity drop-out into final disposal container.

\section{C-5.5 Offgas Treatment System}

The original selection of wet offgas treatment on the CAI was based on high $\mathrm{HCl}$ removal efficiency, excellent particulate removal prior to HEPA filtration, the availability of a liquid waste treatment facility to treat scrub solution blowdown; and this approach is relatively insensitive to swings 
in offgas flow rate, temperature, and composition. Though the same general approach to offgas treatment was adopted for the upgrade, the entire offgas train has been replaced to enhance thermal and corrosion resistance, mechanical durability, and reliability. The solution to the problem was the following: (1) replace the wetted surfaces of the quench tower, venturi scrubber, absorber tower, and ducting entering the HEPA filters with high alloy materials, e.g., the quench, venturi, and absorber vessels with Hastelloy $\mathrm{C}-22$ and the offgas ducting up to the HEPA filters with superaustenitic stainless steel AL-6XN; (2) relocate the $24 \mathrm{~kW}$ electrical resistance superheater immediately downstream of the absorber tower offgas exit; and (3) replace the single HEPA filter housing with a triple bank of tilters in separate housings.

\section{C-5.6 Scrub Solution Recycle System}

The piping in the recycle system was replaced with Hastelloy C-276 and a hydrocyleone was included to remove suspended llash from the recycling scrub solution. The scrub solution pH control was changed to allow more rapid response between the points of $\mathrm{pH}$ measurement and caustic injection.

\section{C-5.7 Instrumentation and Controls}

The original process instrumentation used throughout the CAI was developed in the late 1970)s. State-of-the-art instrumentation and controls have been installed to update the original instrumentation. New field transmitters, recorders, and microcontrollers were incorporated into process monitoring and control functions. Safety interlocks that were based on electro-mechanical relays are now managed by a programmable logic controller. All important process variables are logged on an IBM PC compatible data acquisition system which provides real-time trending, reports, and material and energy balance analysis. Offgas $\mathrm{CO}, \mathrm{CO}_{2}$ and $\mathrm{H}_{2} \mathrm{O}$ levels will be continuously monitored using an in situ nondispersive infrared analyzer mounted on the stack. Online alpha/beta continuous monitors are planned as well.

\section{C-6. GENERAL COMMENTS}

The CAI is a successful, low-volume system that includes enhanced corrosion resistance, stateof-the-art instrumentation, and controls in the offgas system.

\section{C-7. BIBLIOGRAPHY}

Hutchin, D.A., Hazardous Waste Incincration at Los Alamos National Laboratory, brochure, July 1989. 
Koenig, Ralph A., "Summary of Radioactive and Mixed Waste Incineration Technologies Within the Department of Energy Nuclear Weapons Complex," Prepared for Congress of the United States Office of Technology Assessment, June 10, 199().

Vavruska J.S., et al., "Los Alamos Controlled Air Incinerator Upgrade for TRU/Mixed Waste Operations," 1989 Incineration Conference, Knoxville, Tennessee May 1989. 


\section{Appendix D}

Mound Laboratory - Joule-Heated Glass Melter 


$$
\text { D-2 }
$$

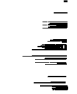




\section{Appendix D}

\section{Mound Laboratory - Joule-Heated Glass Melter}

\section{D-1. FACILITY DESCRIPTION}

The joule-heated glass furnace unit is a $8-1 / 2 \mathrm{ft} \times 5-1 / 2 \mathrm{ft} \times 3-1 / 2 \mathrm{ft}$ combustion chamber sheathed in a $1 / 4$-in. 310 stainless steel skin and lined with $9-12$ in. of an aluminum zirconium silicate fused-cased refractory. This chamber is filled to a depth of $10 \mathrm{in.}$ with soda-lime-silica cullet. The cullet is heated to its melting point $\left(1350^{\circ} \mathrm{F}\right)$ by a propane burner, after which the glass is able to conduct electricity, and the six high-purity iron electrodes, located below the glass surface, assume control of the melt temperature. When the melt has reached a temperature of approximately $2400^{\circ} \mathrm{F}$, liquid and preshredded solid waste is introduced into the burn chamber via the feed hopperiscrew feeder and is immediately ignited by radiant heat. Primary combustion products are swept along the surface of the melt by combustion air streams. Ash from the combustion process falls to the glass surface, where it is eventually incorporated into the melt, while the gaseous combustion products exit the furnace chamber via the offgas tee, and continue on to the wet scrubbing system.

The wet scrubbing system used with the glass furnace was originally developed for use on Mound's cyclone incinerator. In that capacity it has been providing environmentally safe offgas by effectively removing particulates, acid gases, and radioactivity, and reducing offgas temperatures. The offgas system is based on a venturi scrubber for removal of most particulate, caustic addition to the quencher and venturi for acid gas neutralization, and HEPA filters for fine particulate.

\section{D-1.1 Specifications}

Manufacturer

Thermal design capacity

Design throughput capacity

Fecd inpul

Secondary waste streams

Destination of output
Penberthy Electromelt

$175 \mathrm{~kW}$

5() $\mathrm{lb} / \mathrm{hr}$

Plutonium contaminated solvents and oils; mixed LL.W

HEPA filters and scrubber solutions

Not known

\section{D-2. STATUS OF SYSTEM}


The system is in the process of startup. An RCRA trial burn test plan has been submitted for the Part B peimit.

\section{D-3. STATUS OF PERMITS}

RCRA

Interim status; submitted Part B application to EPA for

TSCA

NR

Clean Air (NESHAPs) No

State Air Quality No

Local Air Quality NR

\section{D-4. PUBLIC INVOLVEMENT/PERCEPTION}

There has been little public involvement thus far.

\section{D-5. PROBLEMS/RESOLUTIONS}

\section{D-5.1 Electrodes}

Electrodes are difficult to change out and the problem is magnified because of the short life of electrodes. No solution has been identified.

\section{D-5.2 Draining System}

The system is difficult to drain, no solution has been identified.

\section{D-6. GENERAL COMMENTS}

None.

\section{D-7 BIBLIOGRAPHY}

Armstrong, K.A., et al., "Joule-Heated Glass Furnace System for the Incineration of Low-Level Radioactive Wastes," Monsanto Rescarch Corp., Mound Laboratory Report No. MLM$3018(\mathrm{OP})$. 
Klingler, M.L., et al., "Joule-Heated Glass Furnace Processing of a Highly Aqueous Hazardous Waste Stream," EG\&G Mound Applied Technologies Report No. MLM-3577, March 1989.

Koenig, Ralph A."Summary of Radioactive and Mixed Waste Incineration Technologies Within the Department of Energy Nuclear Weapons Complex," Prepared for Congress of the United States Office of Technology Assessment, June 10, 1990. 
Appendix E

K-25 - Toxic Substances Control Act (TSCA) Incinerator 


\section{Appendix E}

\section{K-25 - Toxic Substances Control Act (TSCA) Incinerator}

\section{E-1. FACILITY DESCRIPTION}

The TSCA incinerator consists of a rotary kiln with feed systems and offgas treatment. Liquid organic wastes are atomized into the kiln through the main burner. If the waste does not provide enough heat release to maintain the kiln at required temperatures, an auxiliary burner can be used to obtain acceptable operating temperatures. Solid waste that is fed by the ram feeder and sludges are maintained in the kiln for 1 to $1-1 / 2 \mathrm{hr}$. The rotating action of the kiln continuously exposes unburned solids to the hot, oxidizing atmosphere, thus ensuring complete organic destruction. Aqueous waste is atomized into the kiln. An induced draft fan maintains subatmospheric pressures in the kiln and forces combustion gases to flow to the secondary combustion chamber (SCC).

As combustion gases and solids exit the kiln, they enter a mix chamber where the gas velocity is significantly reduced. This causes most of the solids to drop out of the gas into the ash handling system. The ash handling system is a water-filled sump with a drag chain to remove the ash from the sump and discharge it into a container.

The SCC receives the kiln combustion gases and secondary liquid wastes that are fired through the secondary burner. After secondary combustion, the offgases pass into the quench chamber where they are cooled to the adiabatic saturation temperature. The venturi scrubber receives the cooled and water-saturated flue gas and removes particulates of one micron and larger and a portion of the hydrochloric acid. A demister is located behin/l the venturi scrubber to remove entrained water and minimize interference with the cross low-packed-bed scrubber. The packed-bed scrubber removes additional soluble and reactive gases such as $\mathrm{HCl}, \mathrm{HF}$, and $\mathrm{SO}_{2}$. The combustion gas is further treated by the ionizing wet scrubber, which removes the fine particulates of $<1 \mu$. Key features of the two-stage, horizontal crossflow scrubber are an ionizer module, a charged particle scrubber, and a recirculating water system. The offgas system is not fitted with HEPA filtration.

\section{E-1.1 Specifications}

Manufacturer

Design thermal capacity

Throughput capacity
IWES

30) MBtu/hr

$2000 \mathrm{lb} / \mathrm{hr}$ of liquids and sludges and $10(0) \mathrm{lb} / \mathrm{hr}$ of solids 
Feed input

Secondary waste streams

Destination of output
Waste potentially contaminated with radionuclides, mainly uranium and trace quantities of technetium. The waste mainly consists of PCB liquids, oils, solvents ind chemical, aqueous wastes of $>50 \%$ water, sludges and solids.

Blowdown liquids

Ash destination is unknown. Liquids will go to the centralized ORNL neutralization facility at K-25.

\section{E-2. STATUS OF SYSTEM}

In process of startup and obtaining required permits.

\section{E-3. STATUS OF PERMITS}

RCRA

Interim status, Part B application submitted, three trial burns conducted.

TSCA

Yes

Clean Air (NESHAPs)

Yes

State Air Quality

Yes

Local Air Quality

NR

\section{E-4. PUBLIC INVOLVEMENT/PERCEPTION}

The public hearing was orderly with no significant negative public reaction.

\section{E-5. PROBLEMS/RESOLUTIONS}

\section{E-5.1 Induced Draft Fan}

The induced draft fan blades constructed out of fiberglass failed and replaced with metal fan blades. 


\section{E-6. GENERAL COMMENTS}

The system performed as expected. There has been more technical support required to operate the incinerator than planned ( $\$ 19$ million per year in operating costs).

\section{E-7. BIBLIOGRAPHY}

Koenig, Ralph A., "Summary of Radioactive and Mixed Waste Incineration Technologies Within the Department of Energy Nuclear Weapons Complex," Prepared for Congress of the United States Office of Technology Assessment, June 10, 1990.

Rogers, T.O. "ORGDP RCRA/PCB Incinerator Facility," Martin Marietta Report No. K/SS-455, March 14, 1986. 


\begin{abstract}
Appendix F
Rocky Flats Plant (RFP) -

Fluidized Bed Incinerator (FBI) Demonstration
\end{abstract}


F-2 


\section{Appendix F}

\section{Rocky Flats Plant (RFP) - Fluidized Bed Incinerator (FBI) Demonstration}

\section{F-1. FACILITY DESCRIPTION}

The FBI is a unique fluidized bed incinerator with three combustors instead of the usual one combustor. The second and third combustors are used as afterburners for the primary combustor, allowing temperatures to be cossiderably lower than conventional fluidized bed incinerators to enhance recovery of plutonium.

Solid wastes are received in 55 gal drums and are manually sorted to separate combustible wastes from noncombustible wastes (c.g., metal and glass) in a glovebox. The combustibles are fed into a low speed, high torque coarse shredder located beneath the sorting-feeding glovebox. The coarse shredded waste falls into a gas stream classifier. A nitrogen gas stream, regulated by a moving vane, separates light particles from dense particles. Dense material falls into the tramp metal glovebox and light shredded material is pneumatically transferred out of the classifier into a cyclone separator. The cyclone drops the coarsely shredded combustibles into a second shredder. The second shredder delivers a finely shredded waste to a hopper that feeds a screw conveyor. The liquid waste feed is pumped into the primary reactor through nozzles.

The primary reactor contains a bed of sodium carbonate and oxidation catalyst, which is tluidized by a flow of compressed air and nitrogen. By design, the primary reactor provides approximately $25 \%$ combustion of the waste material, which supplies sufficient heat for sustaining the temperature of the primary reactor. The low-temperature llameless incineration process and the in situ neutralization of halogen acids, sulfur dioxide, and phosphorus pentoxide formed during combustion minimize incinerator corrosion, with the result that refractory materials are unnecessary.

The hydrocarbon-rich gas from the primary reactor is combusted in the secondary afterburner reactor. The third combustion process in the afterburner catalytic reactor is flameless. 'This reactor serves to oxidize the carbon monoxide in the offgas. A shroud enclosure on the lower third of the catalytic reactor houses a recirculating waster spray cooling system. This cooling system removes approximately $45 \%$ of the total heat of combustion. The afterburner operates at $1022^{\circ} \mathrm{F}$.

Offgases from the primary reactor and secondary afterburner pass into primary and afterburner cyclone separators where the sodium carbonate, catalyst, sodium salts, and thy ash are removed from the gas stream. The next stage of particulate removal is carried out by sintered stainless steel filters. The metal filters serve as a fire barrier and protect the HEPA filters. Particulates collected on the surface of the filter tubes are removed by an automatic blow-back system. The flue gas passes 
through one stage of HEPA filtration and goes to the air ejector. The air ejector provides the force to maintain the FBI system at a negative pressure relative to ambient. It then passes through a second stage of HEPA filters. The flue gas leaves the canyon containment structure and enters a four stage HEPA filtration system.

Ash from the primary and secondary cyclones is automatically discharged to a water cooled and enclosed ash conveyor. The conveyor employs a moving screw that transports the ash to a 55-gal drum located beneath a glovebox at the termination of the screw conveyor.

\section{F.1.1 Specifications}

Manulacturer

Design thermal capacity

Throughput capacity

Feed input

Secondary waste streams

Destination of output

\author{
Rockwell International
}

\section{$1.5 \mathrm{M} \mathrm{Btu} / \mathrm{hr}$}

$180 \mathrm{lb} / \mathrm{hr}$ of solid waste and $88 \mathrm{lb} / \mathrm{hr}$ of liquid waste based on heat values of representative wastes that will be incinerated and the total heat release.

TRU solid and liquid waste

Sodium carbonate and catalyst fines; HEPA filters

WIPP

\section{F-2. STATUS OF SYSTEM}

Unit is shut down because of public concerns and testing problems.

\section{F-3. STATUS OF PERMITS}

RCRA

TSCA

Clean Air (NESHAPs)

State Air Quality

Local Air Quality
No, Part B subrnitted but not approved

NR

Unknown

Yes

NR 


\section{F-4. PUBLIC INVOLVEMENT/PERCEPTION}

There has been intense public involvement in the permitting and operation of the FBI. Negative public reaction and environmental group pressure forced the shut down of this facility.

\section{F-5. PROBLEMS/RESOLUTIONS}

\section{F=5.1 Waste Shredder}

The primary or coarse shredder was equipped with 1.25 in. wide blades. These blades were capable of shredding any waste material tested, but they produced lengthy strings of plastic that fouled the air classifier. The 1.25 in. blades were replaced with .625 -in. wide blades. These thinner blades reduced the amount of plastic strings, but it was necessary to weld steel cleaning bars in the shredder to further alleviate the problem.

The thinner blades required a greater amount of driving torque. The lack of adequate driving power caused the shredder to cycle in the forward and reverse mode extensively when shredding normal combustibles. This was solved by installing a new hydraulic drive motor which operates slower, increasing the total torque by approximateiy $60 \%$.

\section{F-5.2 Air Classifier}

The air classifier occasionally developed a plug in the separation chamber or outlet port when a large percentage of plastic was being shredded. The plugging was hecause of strings of plastic that become snagged and then snare other pieces of combustibles to eventually form a blockage. This problen was solved by changing the position of the movable vane and by manual manipulation through glove-ports and changing the shredder blades.

\section{F-5.3 Waste Feeding System}

The waste is prone to bridging and has occasionally become suspended over the oscillating well. This problem was solved by limiting the fill level of the hopper during operation and redesigning the hopper with a vertical wall.

The tapered screw conveyor was scaled up from a smaller version used in pilot operations. One mechanical failure has cocurred on the larger unit: a gear reducer i.a the drive mechanism of the conveyor falled when some dense. noncompressible material jammed the unit. The gear was replaced and the following two measures were taken to avoid future problems of this nature: first. the diameter of the auger was rrachined down sightly to increase the overall axial clearance within the housing and thus alleviate jamming when conveying dense waste; second, a torque limiter was 
installed in the electrical circuit to automatically control the amount of torque that can be applied to the auger.

\section{F-5.4 Afterburner Reactor}

Pilot scale data was used in the cesign of the afterburner, but the use of a water spray heat removal system added a new, untested dimension to the scaled-up unit. This portion of the design presented problems that necessitated major modifications after several incineration runs.

Catalyst attrition losses from the afterburner were greater than anticipated during the first $200 \mathrm{hr}$ of operation. The losses were believed to be caused by problems in the flue gas distributor. Consequently, the catalyst was transferred from the afterburner and the distributor piping was inspected. One problem was readily apparent: thermal expansion caused weld failures and cracking where the distributor pipes penetrated through the walls of the vessel. The actual causes of high catalyst attrition were attributed to uneven gas distribution owing to piping cracks and the jet grinding effect of the distributor orifices. The problem was solved by positioning the jet downward at $45 \%$ angle and replacing single orifices with groups of smaller orifices of the same total area.

There was a failure of an expansion joint in the flue gas transfer line between the primary reactor and the afterburner. The joint was destroyed by an excessive overheat condition that occurred during a standby period when methanol was being pumped into the transfer line to provide fuel to maintain temperature in the afterburner. The methanol apparently ignited at the point of injection, and the gas velocity was not sufficient to carry the heat of combustion into the afterburner. To resolve this problem, the methanol injection line was relocated nearer to the afterburner at the point where the transfer line branches into four separate lines that supply the flue gas distributor. The velocity of individual gas streams at this point exceeds the methanol tlame front velocity, thus preventing a reocurrence of combustion within the transfer lines.

\section{F-5.5 Offgas System}

During the first incineration run, an excessive pressure drop developed across the sintered metal filters, making it impossible to maintain the necessary negative pressure within the system. The filters were inspected and found to be in good condition. Test results indicated that the filter area was not sufficient to provide the required gas face velocity restriction. New filter cartridges with a larger diameter were then installed in the existing housings.

\section{F-6. GENERAL COMMENTS}

None. 


\section{F-7. BIBLIOGRAPHY}

Kabot, F.J., and D. L. Ziegler, "Development of a Trial Burn Plan for a Mixed Waste Fluidized Bed Incinerator," RFP-4212, 1988.

Koenig, Ralph A., "Summary of Radioactive and Mixed Waste Incineration Technologies Within the Department of Energy Nuclear Weapons Complex," Prepared for Congress of the United States Office of Technology Assessment, June 10, 1990.

Meile, L.J., et al, "Rocky Flats Plant Fluidized Bed Incinerator," Rockwell International Report No. RFP-3249, March 8, 1982.

Meile, L.J., Rocky Flats Plant Fluidized Bed Incinerator Engineering Design and Reference Manual, Rockwell International Report No, RFP-3372, December 23, 1982. 
Appendix G

Savannah River Site (SRS) -

Beta-Gamma Incinerator (BGI) 
G-2 


\section{Appendix G}

\section{Savannah River Site (SRS) - Beta-Gamma Incinerator (BGI)}

\section{G-1. FACILITY DESCRIPTION}

The SRS BGI is a dual chamber controlled-air unit. Combustion air is introduced through several underfire air ports on both sides of the hearth. Waste is pyrolyzed in the fuel-rich primary chamber. Combustion airflow (100-200\% excess) is supplied at the entrance of the secondary chamber to oxidize the partial combustion products. Diesel-oil-fired burners are used to maintain the operating temperatures in each chamber.

Offgases from the secondary chamber pass through a refractory-lined duct before entering the spray quench. The gases leaving the spray quench are maintained above the dewpoint to minimize corrosion and to avoid generating secondary liquid waste streams. The baghouse serves as the first stage of filtration of the cooled offgases. The baghouse contains 135 vertically hanging filter bags. A line precoat is applied to the bags during solvent incineration. The offgases are then passed through prefilters and then through HEPA filters.

Ash is removed from the incinerator's primary chamber semi-continuously by two hydraulic rams. The first ram moves the ash the length of the hearth and tumbles it into an ashdrop. After the ash cools, the second ram pushes the ash the length of the removal duct and into a 55-gal drum. Flash is collected separately at the spray quencher and baghouse.

\section{G-1.1 Specifications}

Manulacturer

Design thermal capacity

Throughput capacity

Feed input

Secondary waste streams

Destination of output
ECP of North Carolina

$5 \mathrm{M} \mathrm{Btu} / \mathrm{hr}$

$380 \mathrm{lb} / \mathrm{hr}$

Suspect radioactive solid waste $(<1 \mathrm{mrad} / \mathrm{mR} / \mathrm{hr}$ at 3 in. from box) and spent radioactive process solvent

HEPA filters and baghouse hags

Ash disposed of in the SRS LLW facility. 


\section{G-2. STATUS OF SYSTEM}

BGI was shut down due to mechanical failures. It was then decided not to restart the unit.

\section{G-3. STATUS OF PERMITS}

RCRA

TSCA

Clean Air (NESHAPS)

State Air Quality

Local Air Quality
NR

NR

Unknown

Unknown

NR

\section{G-4. PUBLIC INVOLVEMENT/PERCEPTION}

There has been no public involvement with this incinerator.

\section{G-5. PROBLEMS/RESOLUTIONS}

\section{G-5.1 Combustion Gas Leakage}

An explosion occurred in the ram feed housing adjacent to the incinerator because of backleakage of combustion gas during a severe process upset and incinerator pressurization. The solution was to specify a forced ventilation of the enclosures adjacent to and around the primary chamber and secondary combustion chamber (SCC) for cooling and removal of possible combustible gases.

\section{G-5.2 Incinerator Pressure}

The primary incinerator pressure indicator was too insensitive to indicate that incinerator pressure had exceeded atmospheric pressure during control instrument balancing. No solution was defined for the problem.

In addition, the system control valve for maintaining negative pressure in the primary chamber was located too far downstream of the primary chamber. This resulted in poor pressure control because of the excessively high lag times hetween pressure feedback control input and system pressure response. Attempts were made to enhance the control instrumentation and the control logic, but they were generally unsuccessful. The best solution would be to relocate the control point closer to the chamber being controlled. 


\section{G-5.3 Emergency Shutdown Controls}

Emergency incinerator shutdown controls are located only in the control room, which can impair a safe shutdown during an evacuation. The solution to the problem was to locate emergency shutdown controls outside the building in an emergency control room.

\section{G-5.4 Purex Solvent Burning}

Purex solvent burning produced a slag that accumulated on the hearth and interfered with ram operations. No solution was developed for this problem.

Combustion of this feed material also generates a high concentration of very small (and somewhat sticky) phosphorus oxide particles in the offgas as the oxide condenses from a gaseous form as it cools. To prevent the phosphorus oxide particles from blinding the bag filters, SRS found that by mixing tetrabutyl titanate with the waste liquid, the phosphorus would bind with the titanium oxide formed in combustion to yield easily filtered particles.

\section{G-5.5 Ash Buildup}

Ash builds up at the end of the stroke of the incinerator box feed ram and causes blockage of boxes. This ash pile has been difficult to remove. A solution was not developed for this problem.

\section{G-5.6 Accessibility for Maintenance}

Major components have poor access for maintenance or removal and there is no lifting capability. The solution is to design major components with easy access for routine maintenance and lifting capability for major maintenance.

\section{G-5.7 Offgas System Corrosion}

Severe corrosion was experienced in the offgas system primarily due to condensation of acid in unlined and uninsulated metal equipment. The solution is to use appropriate materials of construction and use sodium hydroxide to neutralize acids and remove particulates.

\section{G-6. GENERAL COMMENTS}

None. 


\section{G-7. BIBLIOGRAPHY}

Becker, George W., "Savannah River Plant Low-Level Incinerator Program," Third Annual Participants Meeting of the DOE Low-Level Waste Management Program, New Orleans, DuPont Report No. DP-MSD.81-103, November 1981.

Irujo, M. J., et al, "Savannah River Plant Low-Level Waste Incinerator," Incineration of Low-Level Radioactive and Mixed Wastes Meeting, St. Charles, IL, DuPont Report No. DP-MS-86-186, April 1987.

"Investigation Report Toxic Gas Release From the Beta-Gamma Incinerator at the Savannah River Plant on December 9, 1986," Report No. DOE/SR-8(0)2.

Ralph A. Koenig, "Summary of Radioactive and Mixed Waste Incineration Technologies Within the Department of Energy Nuclear Weapons Complex," Prepared for Congress of the United States Office of Technology Assessment, June 10, 1990. 


\section{Appendix $\mathrm{H}$}

\section{Savannah River Site (SRS) - \\ Consolidated Incineration Facility (CIF)}




\section{Appendix $\mathrm{H}$}

\section{Savannah River Site (SRS) - Consolidated Incineration Facility (CIF)}

\section{H-1. FACILITY DESCRIPTION}

The incinerator system design consists of an $8 \times 25 \mathrm{ft}$ rotary kiln primary chamber coupled to a $6 \times 33 \mathrm{ft}$ horizontal , cylindrical SCC. Liquid wastes with high ash content and aqueous wastes will be fed to the rotary kiln through a burner nozzle and high-heat burner. HEPA filtered enclosures will be provided around the rotary kiln and SCC feed and burner maintenance area to prevent the release of radioactive material to the environment. The nominal solid waste residence time in the kiln is 90 minutes and the minimum offgas residence time is two seconds in the SCC.

Ash from the kiln will be deposited into a waste trough (ash-out) that provides a vacuum seal with the rotary kiln. Large pieces of ash will be removed from the ash-out by using a device similar to a backhoe and deposited into a 55 gal drum. Cement and water will be remotely added to the drum. The cement and water in the drum will be mixed by a tumbling action to produce a stabilized waste product.

Offgas leaving the SCC will enter a quench vessel and be adiabatically cooled to saturation. The quench offgas will enter a stream atomized free-jet scrubber, which will remove particulates and acid gases such as hydrogen chloride and sulfur oxides. The scrubbing mixture will then enter a cyclone separator where liquid-gas separation will take place. The scrubbed offgases will proceed through a high efficiency mist eliminator that will remove residual particulate and entrained water droplets. Saturated scrubbed offgas will pass through a reheater and be heated to a temperature of approximately $3000 \mathrm{~F}$ before passing through HEPA filters, induced draft blowers, and exiting through the process stack. Fiber reinforced plastic (FRP) will be used for construction of the offgas system surge tanks and most of the ductwork downstream of the quench. Blowdown from the quench recirculation line will pass through a crossflow filter system to concentrate suspended solids up to $10 \mathrm{wt} \%$ and be pumped to one of two 5000 gal agitated FRP hold tanks. Blowdown waste will be transferred by tank truck to a large onsite cement stabilization facility, which processes similar type wastes produced from other SRS facilities.

\section{H-1.1 Specifications}

Manufacturer

Design thermal capacity
John Zinc

$10 \mathrm{M} \mathrm{Btu} / \mathrm{hr}$ 
Throughput capacity

Feed input

Secondary waste streams

Destination of output
$720 \mathrm{lb} / \mathrm{hr}$ of solid and $187 \mathrm{lb} / \mathrm{hr}$ of liquids

Low-level solid and liquid mixed waste

Blowdown liquids and HEPA fillers

Ash will be solidified for on site disposal in mixed waste disposal vaults. The liquids will go to the SRS Y area for processing.

\section{H-2. STATUS OF SYSTEM}

The system design is complete. The facility is waiting for a RCRA approval to be granted and NEPA (EA) approvals to begin construction.

\section{H-3. STATUS OF PERMITS}

RCRA

TSCA

Clean Air (NESHAPs)

State Air Quality

Local Air Quality
Part $\mathrm{A}$ and $\mathrm{B}$ permit applications submitted to the state

NR

Yes - but being revised

No

NR

\section{H-4. PUBLIC INVOLVEMENT/PERCEPTION}

There has been no public involvement to date.

\section{H-5. PROBLEMS/RESOLUTIONS}

\section{H-5.1 Salt Loading of HEPA Filters}

PREPP reported high loading of salt in the HEPA filters. The solution to the problem for SRS was to conduct tests on the salt particulate carryover from the quench and scrubber systems and to design the system based on the results. 


\section{H-5.2 Kiln Seals}

PREPP experienced severe problems with the standard seals delivered with the rotary kiln. PREPP redesigned the seals and did cold testing of the new seals. As a solution to the problem the CIF rotary kiln manufacturer redesigned the seals to be similar to the PREPP design. SRS is planned a hot (thermal) test program the new seals.

\section{H-6. GENERAL COMMENTS}

The system has been designed to meet all regulatory requirements. It is a state-of-the-art facility.

\section{H-7. BIBLIOGRAPHY}

Weber, D.A., "The Savannah River Plant Consolidated Incineration Facility," Incineration of LowLevel Radioactive and Mixed Wastes Conference, St. Charles, IL, Report No. DP-MS-86-171, April 1987.

Koenig, Ralph A., "Summary of Radioactive and Mixed Waste Incineration Technologies Within the Department of Energy Nuclear Weapons Complex," Prepared for Congress of the U.S. Office of Technology Assessment, June 10, 1990.

Bennett, G.E., "CIF Design Basis for an Integrated Incineration Facility," Charles T., Main, Inc., Westinghouse Report No. WSRC-MS-91-134, 1991.

Krolewski, J.F., et al., "Consolidated Incineration Facility Model Videotape," International Conference on Incineration of Hazardous, Radioactive, and Mixed Waste, San Francisco, DuPont Report No. DP-MS-88-68, May 1988. 


\section{Appendix I}

\section{Savannah River Site (SRS) - \\ Defense Wastes Processing Facility (DWPF)}




\section{Appendix I}

\section{Savannah River Site (SRS) - \\ Defense Wastes Processing Facility (DWPF)}

\section{1-1. FACILITY DESCRIPTION}

The DWPF at the SRS will vitrify waste in a glass melter into a borosilicate glass, pour it into stainless steel canisters, weld and decontaminate the canisters, and store them for shipment to a geologic repository. While the vitrification plant is the key facility in the SRS waste disposal program, there are other important facilities and activities. Feed for the DWPF is in interim storage in doubleshell tanks. A necessary first step for feed preparation is separation of the sludge and supernate fractions. Sodium tetraphenyl borate is added to the supernate in the underground storage tanks to precipitate the cesium present. The cesium tetraphenyl borate precipitate is then pumped to the HLW vitrification process, while the decontaminated liquid is incorporated into saltstone (a cementbased waste form) and disposed of as LLW in onsite vaults. The sludge, which contains most of the remaining actinides and fission products, is removed from the tanks and converted to borosilicate glass in the DWPF.

The offgas cleaning systern will use components that are functionally equivalent to the CIF described above. The offgases from this system pass through a large sand filter that uses gradually smaller diameter layers of sand to trap very fine particulate.

\section{I-1.1 Specifications}

Marufacturer $\quad$ Multiple firms

Throughput capacity $\quad 82 \mathrm{lb} / \mathrm{hr}$

Feed input High level sludge and liquid mixed waste

Secondary waste streams $\quad$ Sand filters

Destination of output Long-term disposal has not been defined.

\subsection{STATUS OF SYSTEM}

Construction is nearing completion. SRS is preparing for a simulated (nonradioactive) waste test. 


\section{I-3. STATUS OF PERMITS}

RCRA

TSCA

Clean Air (NESHAPs)

State Air Quality

Local Air Quality
Unknown

NR

Yes

Unknown

NR

\section{1-4. PUBLIC INVOLVEMENT/PERCEPTION}

There has been no public involvement to date.

\section{1-5. PROBLEMS/RESOLUTIONS}

Hydrogen generation

There is the possibility of generating hydrogen in the feed processing area. The solution has not been defined.

\section{1-6. GENERAL COMMENTS}

None.

\section{I-7. BIBLIOGRAPHY}

Bickford, D. F., et al, "Control of Radioactive Waste-Glass Melters: Part 3--Glass Electrical Stability," DuPont Report No. DP-MS-88-14, May 1988.

Koenig, R. A., "Surnmary of Radioactive and Mixed Waste Incineration Technologies Within the Department of Energy Nuclear Weapons Complex," Prepared for Congress of the United States Office of Technology Assessment, June 10, 1990.

Wodrich, D. D., et al, "Progress in Defense High-Level Waste Disposal," Westinghouse Report No. WHC-SA-0075, February 1988. 


\section{Appendix J}

Scientific Ecology Group (SEG) Incinerator 


\section{Appendix $\mathrm{J}$}

\section{Scientific Ecology Group (SEG) Incinerator}

\section{J-1. FACILITY DESCRIPTION}

The SEG incinerator in Oak Ridge, Tennessee, is referred to by the manufacturer as a hybrid incinerator, incorporating several different technologies. The primary chamber is operated in a substoichiometric condition. However, the char/ash residue is conveyed into separate chambers where the carbon is burned out in an excess air environment.

The combustion gases from the primary chamber and the ash combustion chambers are drawn into a secondary chamber, and then into a tertiary chamber for added residence time for complete burnout of the combustible material released during substoichiometric burning. The combined residence time in the secondary and tertiary chambers is approximately three seconds. In addition to the long gas residence time, the incinerator consists of unique internal walls and air distribution parts designed to enhance turbulence and mixing of the gases. For hard-to-destroy waste, the secondary and tertiary chambers can operate at temperatures up to $2370^{\circ} \mathrm{F}$, but $1830-2190^{\circ} \mathrm{F}$ is normal for the secondary chamber and $1650-2010^{\circ} \mathrm{F}$ is normal for the tertiary chamber.

For temperature control, each chamber is equipped with a burner. However, the primary chamber burner is only used during incinerator heat up and the tertiary chamber burner is rarely used because it is needed only when waste with a very low energy content or a very low volatile matter content is burned. The gas residence time in this chamber is approximately one second. Therefore, only nonhazardous materials will likely be processed through this burner even when the facility is permitted to burn mixed waste.

The waste processed at SEG varies from contaminated sewage sludge to rags, paper, cloth, etc. The waste acceptance criteri, is basically a sitewide criteria as nearly all waste received is mixed together and must be hand-; orted by SEG to go to the appropriate process.

The offgas train cons sts of a boiler to cool the flue gases, a baghouse and HEPA filters to remove particulate, and a quencher/packed tower to remove acid gases.

The baghouse consists of four separate chambers with only three being required for operation. In this manner, some degree of baghouse redundancy is obtained. With all four chambers online, the air-to-cloth ratio is $3.3: 1$. With only three chambers on-line, the air-tio-cloth ratio is $4.4: 1$. After the baghouse there are redundant HEPA banks with each bank utilizing 30/30 prefilters, 12-in. intermediate filters, and 12 in. HEPA filters. The quencher/scrubber is a standard design using a common sump with $20 \% \mathrm{NaOH}$ as the scrubbing agent. 
The by-products from the incineration process are handled in the following manner: hearth ash that fits the Nuclear Regulatory Commission (NRC) definition of Class A waste is compacted resulting in an additional 2-4:1 volume reduction. Class B (or nearly Class B) waste is not compacted because the volume reduction would result in higher radiation levels on a per volume basis. Flash from the boiler and the baghouse is normally EP Toxic and is therefore solidified with cement or an epoxy resin. Plans are underway to vitrify the flash. Scrubber liquor blowdown is evaporated down to a paste using a thin film evaporator. After evaporation, the salts are dried in either a heated ribbon blender or by compression using a patented quick dry system (originally developed for dewatering spent resins). Once dewatered, the salt can then be compacted resulting in a solid salt monolith. These waste by-products are then sent to a commercial radioactive waste disposal facility.

\section{J-1.1 Specifications}

Manufacturer

Design thermal capacity

Throughput capacity

Feed input

Secondary waste streams

Destination of output
Envikraft, Helsingoer, Denmark

$11.9 \mathrm{M} \mathrm{Btu} / \mathrm{hr}$

$1000 \mathrm{lb} / \mathrm{hr}$ of solid and $30 \mathrm{gal} / \mathrm{hr}$ of liquid

LLW solids and power plant waste oil

HEPA filters, baghouse bags, scrubber solutions

One of the commercial radioactive waste disposal sites

\section{J-2. STATUS OF SYSTEM}

The facility is operational and, except for maintenance and repairs, has been operational since startup in November, 1989. Plans are under way to obtain a RCRA Part B Permit. Therefore, at this time no mixed waste has been processed but SEG hopes to do so in the near future.

\section{J-3. STATUS OF PERMITS}

RCRA

TSCA

Clean Air (NESHAPs)
NR (plan to obtain a Part B permit in the future)

NR

Yes 
State Air Quality $\quad$ Yes

Local Air Quality $\quad$ NR

\section{J-4. PUBLIC INVOLVEMENT/PERCEPTION}

Public involvement/perception has not been a problem with the public in the Oak Ridge area. The public appears to readily accept this type of activity.

\section{J-5. PROBLEMS/RESOLUTIONS}

\section{J-5.1 Heat Buildup}

There was a buildup of heat within the incinerator building. High air temperatures in certain regions of the building resulted in failures of instrumentation and other sensitive components. These failures caused several delays in operation that ultimately cost more in lost income than the failed components were worth. This problem was resolved by installing a massive air conditioner.

\section{J-5.2 Feed Charging Conveyor System}

There were frequent delays and lost income due to the feed charging conveyor system. Waste boxes (some weighing in excess of $600 \mathrm{lb}$ when full and weighing approximately $200 \mathrm{lb}(\mathrm{s}$ ) when empty) would bunch up and jam together, hang up on the conveyor, not move at all, etc. Resolution of this problem required modification of the conveyor process logic control program and the conveyor switches and sensors.

\section{J-5.3 Blinding of the Boiler Tubes and Baghouse Bags}

There was an earlier-than-desired shutdown because of blinding of the boiler tubes and the baghouse bags. This blinding problem was caused by the entrainment and then plating out of particulate (to some degree this is actually a condensation of molten particulate). The problem within the boiler was mitigated by installing sonic horns, which cause acoustic vibrations, and help keep the particulate from building up into a deep layer. The acoustic horns have not resulted in the same benefit in the baghouse, so bag blinding continues to be a problem. To get around this problem, the induced draft fan draft was increased.

One of the major sources of the particulate that would lead to the blinding was from atomizing and combusting dirty used oils in the tertiary burner. Various solutions were attempted to resolve this problem, but none were found that mitigated the carryover and blinding to the degree that would allow SEG to meet its financial goals. As a result, a whole new separate oil burning system has been 
installed to dispose of oil. With the exception of using the incinerator stack, the offgas train is totally separate from the incinerator offgas train.

\section{J-5.4 Slagging}

A source of concern has been the slagging of wastes and subsequent attack on the refractory. Although this is an expected problem, the degree and speed of attack was considered abnormal. To mitigate this problem a higher alumina mordenite-based refractory is being used.

\section{J-5.5 High Maintenance of Monitors}

The $\mathrm{O}_{2}$ and $\mathrm{CO}$ monitors continue to be a high maintenance problem. Relocation of the $\mathrm{CO}$ monitors to downstream of the boiler has helped, but frequent maintenance is still a requirement. The $\mathrm{O}_{2}$ monitors have had problems with electronic failures (because of high heat) and materials problems. Selection of higher grade materials has solved some of these problems and the building air conditioner also has helped. However, frequent servicing is still required.

\section{J-5.6 Ash Transport System}

Excessive problems with the ash transport system have also been experienced. The causes of these problems have basically been caused by tramp metal objects in the waste. To help resolve this problem, additional quality assurance procedures were applied to waste sorting operations and some design changes were made to the ash transport equipment to increase strength when under a physical load at high thermal conditions.

\section{J-5.7 Evaporator System}

The evaporator frequently required shutdowns for cleaning. Furthermore, its throughput was well below rated capacity. These problems required numerous solutions. Scrub liquor feed to the evaporator was treated to lower the $\mathrm{pH}$. New feed controls, pumps, piping, etc., were added. Therefore, the system was almost completely overhauled.

\section{J-6. GENERAL COMMENTS}

In general, it is a good system. However, the system does have some attributes that could be improved upon. The use of spray drying technology would probably have been less troublesome and $k$ is costly than the use of a thin film evaporator and a ribbon blender. Furthermore, boiler exhaust temperature is somewhat limited by the pressure limits of the boiler. There are times when a higher offgas temperature would be desirable. Unfortunately, such temperatures are not available without increasing the steam pressure heyond the capabilities of the boiler. 


\section{J-7. BIBLIOGRAPHY}

All of the information presented in this section was submitted by J. D. Dalton, the SEG Project Engineer for the incinerator design and installation, and the program manager for waste incineration until June 1991. 

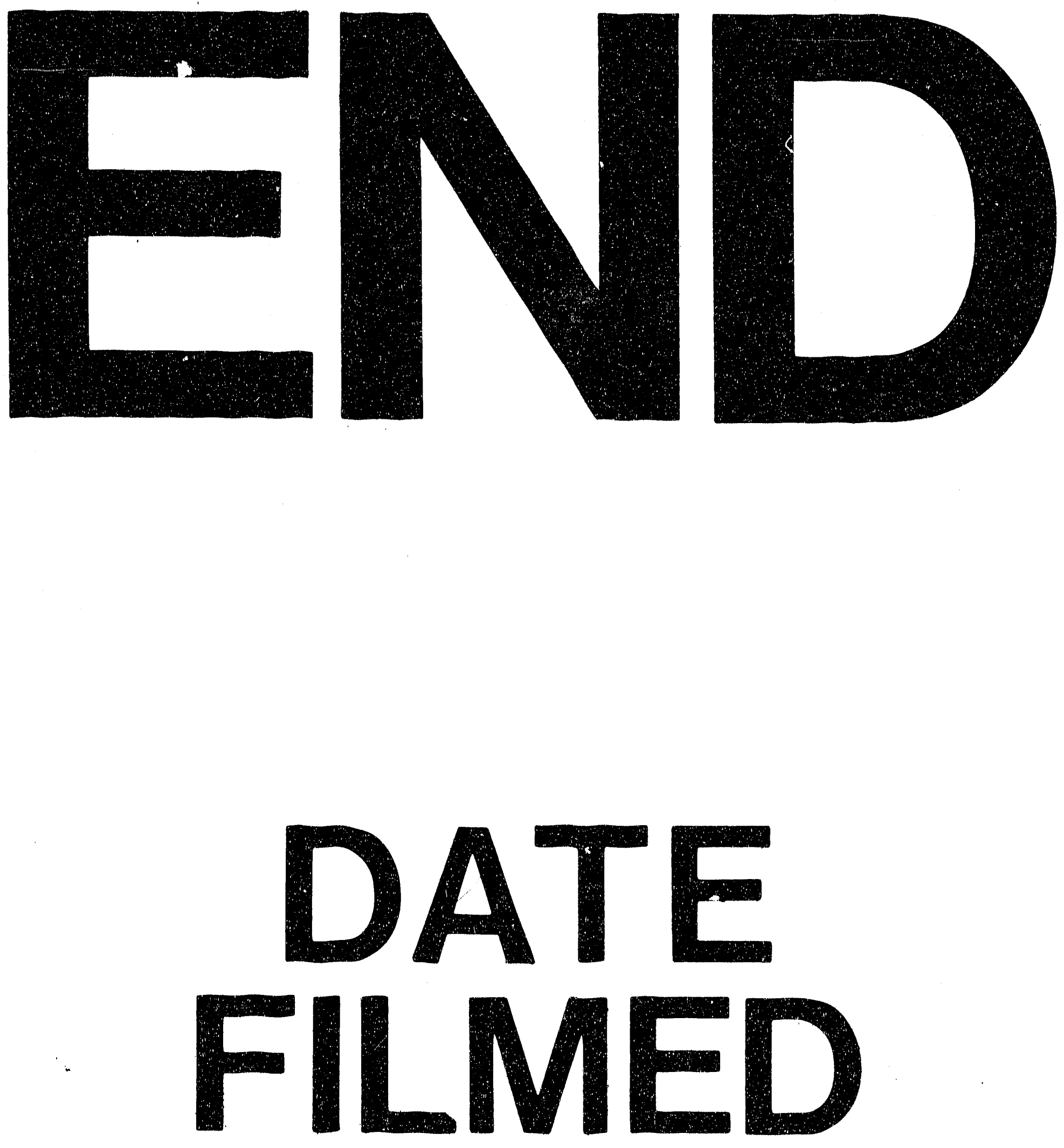

㝵

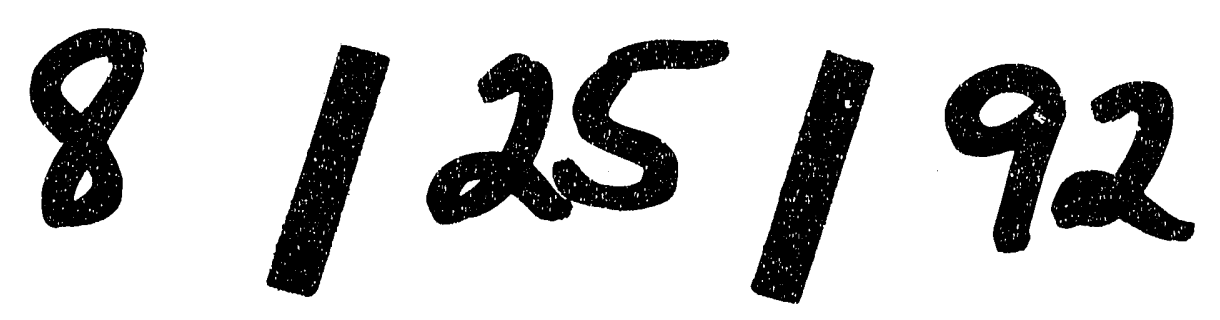




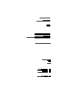

